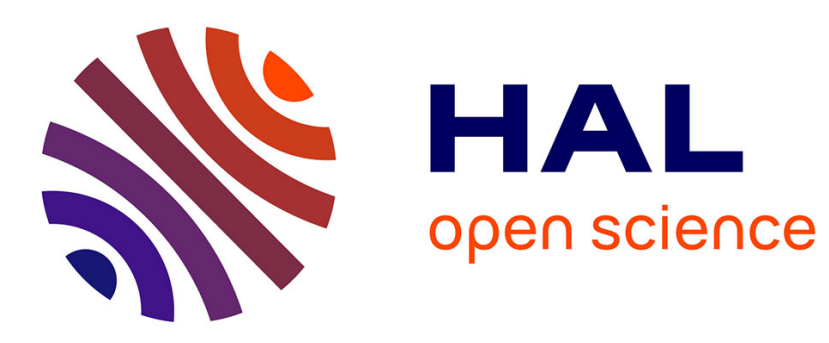

\title{
Molecular Data Reveal the Presence of Three Plocamium Lamouroux Species with Complex Patterns of Distribution in Southern Chile
}

\author{
Alejandro Montecinos, Oscar R Huanel, María Ramírez, Marie-Laure
}

Guillemin

\section{To cite this version:}

Alejandro Montecinos, Oscar R Huanel, María Ramírez, Marie-Laure Guillemin. Molecular Data Reveal the Presence of Three Plocamium Lamouroux Species with Complex Patterns of Distribution in Southern Chile. Cryptogamie Algologie, 2021, 42 (1), 10.5252/cryptogamie-algologie2021v42a1. hal-03146753

\section{HAL Id: hal-03146753 \\ https://hal.sorbonne-universite.fr/hal-03146753}

Submitted on 19 Feb 2021

HAL is a multi-disciplinary open access archive for the deposit and dissemination of scientific research documents, whether they are published or not. The documents may come from teaching and research institutions in France or abroad, or from public or private research centers.
L'archive ouverte pluridisciplinaire HAL, est destinée au dépôt et à la diffusion de documents scientifiques de niveau recherche, publiés ou non, émanant des établissements d'enseignement et de recherche français ou étrangers, des laboratoires publics ou privés. 
1

2 SPECIES WITH COMPLEX PATTERNS OF DISTRIBUTION IN SOUTHERN

3 CHILE.

4

5 Alejandro E. Montecinos ${ }^{1}$, Oscar R. Huane ${ }^{2,3}$, María E. Ramírez ${ }^{4}$, Marie-Laure 6 Guillemin ${ }^{1,3}$.

7

8

$9 \quad$ Universidad Austral de Chile, Casilla 567, Valdivia, Chile.

10

11

Corresponding author: marielaure.guillemin@gmail.com

Running title: Plocamium species complex in southern Chile. 
Plocamium is a widespread genus for which forty-five species are currently recognized. However, classical taxonomy, based only on morphological characters, is problematic within this genus. The use of molecular tools has uncovered cryptic genetic species, mistakenly grouped under the name of morphological species that are common and widespread (including the generitype Plocamium cartilagineum). The aim of this work was to evaluate the species diversity of Plocamium in southern Chile. For this purpose, three independent molecular markers were sequenced in samples collected from seven populations located between $41^{\circ} \mathrm{S}$ and $54^{\circ} \mathrm{S}$. The species diversity was evaluated using phylogenetic reconstructions and two independent methods for species delimitation (ABGD and GMYC). The outcomes of each method were congruent, suggesting the presence of three species in southern Chile. One species, named Plocamium sp. 1, is restricted to Punta Guabún, the only locality sampled north of the biogeographic barrier of the $42^{\circ} \mathrm{S}$. The other two species, Plocamium sp. 2 and 3 are distributed in sympatry in Patagonia and Tierra del Fuego. The three Chilean species form a clade phylogenetically close to sequences obtained from New Zealand and Australia and a divergence along the coasts of Chile after past transoceanic dispersal is proposed. We propose that divergence in glacial microrefugia could have subsequently happen in the southern part of the coast, this hypothesis being supported by the strong impact of glacial maxima on population dynamics, especially in Plocamium sp. 3. 

ESPÈCES DE PLOCAMIUM PRESENTANT UN PATRON COMPLEX DE DISTRIBUTION DANS LE SUD DU CHILI

RESUMÉ

Quarante-cinq espèces sont actuellement reconnues dans le genre Plocamium, un genre présentant une très ample distribution. Cependant, la taxonomie classique, basée uniquement sur les caractères morphologiques, est problématique au sein de ce genre. L'utilisation d'outils moléculaires a permis de révéler l'existence d'espèces génétiques cryptiques, groupées par erreur sous 
73 des phénomènes postérieurs de divergence en micro-refuges glaciaires comme

74 moteur de la spéciation en Patagonie et en Terre de Feu. Cette hypothèse est

75 étayée par le fort impact des maxima glaciaires sur la dynamique des

76 populations, en particulier dans le cas de Plocamium sp. 3.

77

78 Mots clés: Délimitation d'espèces, espèces génétiques, dispersion à longue

79 distance, spéciation, Rhodophyta, algues rouges. 


\section{INTRODUCTION}

Plocamium Lamouroux is a cosmopolitan genus of red seaweed for which 45 species have been recognized to the date (Guiry \& Guiry 2020). These species have been recorded from the Arctic to the Antarctic, in intertidal and subtidal waters (Wynne 2002). This genus has recently received more attention due its relevance in the production of bioproducts (Calegario et al. 2019), including anticancer molecules (Antunes et al. 2011; Alves et al. 2018), herbicides (Gressler et al. 2011; Pereira \& Vasconcelos 2014) and molecules with anti-herbivore properties (San-Martin et al. 1991; Pereira \& Costa-Lotufo 2012). Thus, the development of molecular studies allowing clear species recognition and a better understanding of the evolutionary history of this genus, are critical for subsequent research on these biomolecules of potential importance.

Traditional taxonomy of Plocamium species is based on the number of ramuli (i.e., small protrusions occurring along the thalli main or secondary axes) in alternating series, the width, colour, length, consistency of the thallus, the morphology of the lower ramulus, the arrangement of tetrasporangial structures and cystocarps (Simons 1964; Womersley 1971; South \& Adams 1979; Gabrielson \& Scagel 1989; Cremades et al. 2011). However, these morphological characters have been recognized as insufficient to describe and distinguish between some species (Yano et al. 2004; Saunders \& Lehmkuhl 2005; Cremades et al. 2011). For example, the generitype species, Plocamium cartilagineum (Linnaeus) P.S.Dixon is purportedly very widespread, being recorded in the North Atlantic, eastern and western North Pacific, northern Arabian Sea, Australia, New Zealand, Antarctica and Chile (Bischoff-Basmann \& Wiencke 1996; Wynne 2002). However, molecular studies have demonstrated that specimens named as 
$P$. cartilagineum based on morphological characters actually represented various cryptic species that could be easily distinguished genetically. For example, in a study using molecular nuclear marker LSU sequences for numerous morphological specimens of $P$. cartilagineum from northern Europe, four genetic cryptic species were revealed (Saunders \& Lehmkuhl 2005). Moreover, another case of cryptic genetic species has been reported using the molecular marker 5P-COI, in individuals of $P$. angustum (J.Agardh) J.D.Hooker \& Harvey from Australia and New Zealand (Cremades et al. 2011).

Contrasting with $P$. cartilagineum and $P$. angustum, some taxonomically recognized species, as for example P. nanum G.W.Saunders \& Lehmkuhl, show restricted distributions (Saunders \& Lehmkuhl 2005) probably linked to the presence of biogeographical barriers. Biogeographical barriers are zones defined by rapid changes in biota that can act as barriers to migration (Dawson 2001). In the marine realm, biogeographical barriers have often been associated with landscape features, such as the presence of strong currents or topographical features (e.g., sandy beaches, river mouth, sea mount) limiting gene flow between populations and have been reported as important drivers of speciation, especially in taxa presenting low dispersal capacity (Avise 2000; Kuo \& Avise 2005). Deep phylogeographic discontinuities, congruent with biogeographic barriers, have commonly been encountered in widespread species with distributions encompassing various biogeographic areas (Dawson 2001; Hurt et al. 2009). For example, numerous studies have uncovered deep genetic divergence in coastal marine taxa that coincide with recognized transition zones, such as the California transition zone (Dawson 2001; Kelly \& Palumbi 2010) and the $30^{\circ} \mathrm{S}-33^{\circ} \mathrm{S}$ area located along the Chilean coast (Tellier et al. 2009; 
Montecinos et al. 2012; Haye et al. 2014). These transition zones have been

related to the effect of historical processes, mostly linked to eustatic or climatic changes associated with Pleistocene glacial cycles (Avise 2000). In the case of Plocamium, various widespread morphological species, encompassing more than one biogeographic area, have been reported. In these taxa, the use of molecular markers and genetic species delimitation approaches can help in reevaluating species diversity and distribution.

The Chilean coast is subdivided in three major biogeographical regions (Camus 2001): the Peruvian Province (PP), located from Peru to a southern limit around $30-33^{\circ} \mathrm{S}$ on the northern coast of Chile; the Magellanic Province (MP) extending from Cape Horn ( $\left.56^{\circ} \mathrm{S}\right)$ north to $41-42^{\circ} \mathrm{S}$ (Chiloé Island) and an Intermediate Area (IA) limited by the PP and MP provinces. These biogeographical regions are characterized by distinct biota from warm-temperate in PP to cold-water and subAntarctic species in MP. The IA is characterized by a gradual overlap of biota characteristic of the other two provinces (Camus 2001). Phylogeographic breaks concordant with the biogeographic limit at $41^{\circ} \mathrm{S}-42^{\circ} \mathrm{S}$ have been reported for various marine or coastal species, such as Acanthina monodon Pallas, a brooding gastropod, (Sánchez et al. 2011) and the Patagonian otter Lontra provocax Thomas (Vianna et al. 2011). The coastline north of $42^{\circ} \mathrm{S}$ is continuous, linear and dominated by rocky shores only intersected by a few small rivers and sandy beaches, while a high density of islands, fjords and channels, influenced by sub-Antarctic oceanographic and climatic conditions, characterizes the shoreline south of $42^{\circ} \mathrm{S}$. These distinct coastal morphologies are the results of major topographic transformations due to interglacial/glacial cycles during the Pliocene and Pleistocene in southern Chile (Mercer 1976; McCulloch et al. 2000). 
155 During glacial maxima, in particular during the Last Glacial Maximum (LGM, 15620,000 years ago), ice sheets covered a broad region of southern Chile from the 157 Chiloé Island at $41^{\circ} \mathrm{S}$ to Cape Horn at $56^{\circ} \mathrm{S}$ (Hulton et al. 2002; Saillard et al. 2009). Glacial periods were characterized by the retraction of the temperate biota in glacial refugia while interglacial periods were characterized by range expansion of these species in areas previously covered by ice.

Along the Chilean coast, three species of Plocamium identified using morphology have a distribution range that span more than one Chilean bioregion: $P$. cartilagineum (in the Peruvian Province, the Intermediate Area and the Magellanic Province), P. secundatum (Kützing) Kützing (in the Peruvian and Magellanic Province), and $P$. pacificum Kylin (in the Peruvian Province and Intermediate Area) (Etcheverry 1986; Ramírez \& Santelices 1991; Ramírez 2010). In addition to the extensive distribution of these morphological species, cryptic species have already been reported in $P$. cartilagineum (Saunders \& Lehmkuhl 2005; Cremades et al. 2011), casting doubts about Plocamium diversity and distribution in Chile. The present work aims to explore Plocamium species diversity and evolutionary history in southern Chile $\left(41^{\circ} \mathrm{S}-54^{\circ} \mathrm{S}\right)$ using genetic markers encompassing the three cell compartments (i.e., mitochondria, chloroplast and nucleus). Using these molecular data sets, we applied different methods to delimit species (as conceptualized by the phylogenetic species concept; de Queiroz 1998) and improve knowledge on Plocamium diversity. We hypothesized that genetic species, if existent, will show distributions limited by

177 the biogeographic barrier at $42^{\circ} \mathrm{S}$ and that species encountered in Patagonia and 178 Tierra del Fuego will present historical population dynamics (i.e., contraction 
179 during the LGM and recent expansion) strongly affected by the glacial/interglacial 180 cycles.

181181

\section{MATERIALS AND METHODS}

A total of 107 individuals of Plocamium spp. were collected from 7 localities (Table 1). One locality was located north of the $42^{\circ} \mathrm{S}$ (i.e., Punta Guabún) and six localities were located south of the $42^{\circ} \mathrm{S}$ (i.e., San Gregorio, Parque Chabunco, Faro Porvenir, Los Canelos, Faro San Isidro and Fiordo Yendegaia). Intertidal samplings were conducted during diurnal low tide in Los Canelos and Fiordo Yendegaia while subtidal samplings were done by means of SCUBA diving in the rest of the localities studied. Each sample corresponds to a single frond cut from an isolated holdfast.

In the field, all the samples were first named ' $P$. cartilagineum'. However, more precise observations in the lab show that some individuals from the southern part of the country presented a ramification pattern not fully congruent with the one expected for $P$. cartilagineum (slender ramuli, not all ramification unilateral, very bushy in appearance). In the same way, samples from Punta Guabún did not present the typical $P$. cartilagineum morphology. These small plants were characterized by an intense red color with sympodial branching characterized by profuse ramifications almost from the base and third and fourth order branches arranged in a scalloped manner. Because of these slightly distinct morphologies and since only a few mature tetrasporophytes were sampled we choose to refer to all individuals studied here as Plocamium spp. For most individuals (i.e., 96) 
only small tissue fragments were conserved in silica and no observation in the lab could be made. The 11 samples guarded as voucher specimens are housed in the herbarium of the National Museum of Natural History, Chile (SGO, see voucher numbers in Supplementary Table 1)

DNA extraction, PCR amplification, sequencing and sequence alignment

Dry tissues were ground by hand in liquid nitrogen and DNA was extracted using extraction kit E.Z.N.A.® Poly-Gel DNA Extraction (Omega Bio-Tek Inc., Norcross, USA). Three independent genetic markers were used to provide complementary species identification based on molecular criterion: a partial sequence of the mitochondrial Cytochrome c Oxidase I gene (5P-COI); a partial sequence of the plastid gene $r b c \mathrm{~L}$, encoding the large subunit of the ribulose-1,5-bisphosphate $(r b c \mathrm{~L})$ and the partial large subunit ribosomal RNA gene (LSU). The amplification of $5 \mathrm{P}-\mathrm{COI}$ was performed, for all specimens sampled, using the primers developed by Saunders (2005). The amplification of the $r b c L$ marker was performed for a subset of samples $(n=18)$ using the primers developed by Hommersand et al. (1994). The LSU was amplified as three overlapping fragments with previously published primer combinations (Harper \& Saunders 2001), in a subset of five samples. For the 5P-COI, PCR were performed using conditions described in Dubrasquet et al. (2018) while rbcL and LSU markers were amplified using conditions described in Hommersand et al. (1994) and Harper \& Saunders (2001), respectively. For both $r b c L$ and LSU genes, sub samples included individuals from the three genetic groups recovered by the $5 \mathrm{P}$ COI (more details in the results section below). PCR products were purified using commercial kit E.Z.N.A.® DNAProbe Purification (Omega Bio-Tek Inc., Norcross, 
228 USA) and sequenced with primers used for amplification at the AUSTRAL-omics

229 Core-Facilities (Valdivia, Chile). Sequences were aligned manually using Mega

$230 \mathrm{X}$ (Kumar et al. 2018) and checked by eye; only traces with high quality values and no ambiguities were retained for further analyses.

233 Phylogenetic analyses

234 To explore phylogenetic relationships between Plocamium species, 250 5P-COI sequences from the genus available in GenBank were added to our data set. In the same way, 24 and 20 sequences from GenBank were added to the rbcL and

237 LSU data sets, respectively. Phylogenetic analyses were conducted 238 independently for each gene, using both Maximum Likelihood (ML) and Bayesian 239 Inference $(\mathrm{BI})$ methods. ML analyses were performed using W-IQ-Tree

240 (Trifinopoulos et al. 2016). The best-fit substitution model was selected using the Bayesian Information Criterion (Kalyaanamoorthy et al. 2017) implemented in WIQ-Tree. The selected model was $\mathrm{K} 3 \mathrm{Pu}+\mathrm{F}+\mathrm{I}+\mathrm{G} 4$ for the $5 \mathrm{P}-\mathrm{COI}, \mathrm{TN}+\mathrm{F}+\mathrm{I}+\mathrm{G} 4$ for the $r b c \mathrm{~L}$ and $\mathrm{GTR}+\mathrm{F}+\mathrm{l}+\mathrm{G} 4$ for the LSU. BI analyses were conducted using MrBayes v3.2.7 (Ronquist et al. 2012). Two independent analyses were run using, for each one, four chains and 20 million generations. Trees and parameters were sampled every 1,000 generations and the default parameters

247 for temperature and branch swapping were used. The first $20 \%$ of the sampled trees were discarded as "burn-in" to ensure stabilization. The remaining trees were used to compute a consensus topology and posterior probability values.

250 The split frequency (variance among the four independent runs) was below 0.005 , 251 confirming that the posterior probability distribution was accurately sampled. 
253 Delimitation of genetic species

254 To evaluate the existence of genetic species, two independent analyses were 255 conducted using the 5P-COI dataset. First, the Automatic Barcode Gap 256 Discovery (ABGD) was remotely at 257 https://bioinfo.mnhn.fr/abi/public/abgd/abgdweb.html. ABGD identifies a value 258 separating the frequency distribution of intraspecific pairwise genetic distances 259 from the ones of interspecific pairwise genetic distances, even when they overlap, 260 and use it as a threshold to delimit species (Puillandre et al. 2012). We computed 261 Kimura two-parameter (K2P) genetic distances and used default ABGD settings. 262 Second, a General Mixed Yule Coalescent (GMYC) analysis was run. GMYC 263 identifies a threshold value for the shift in branching rate from coalescent lineage 264 branching to interspecific diversification on an ultrametric tree and explicitly 265 delimits "independently evolving" clusters (i.e., putative species; Pons et al. 2006; 266 Monaghan et al. 2009). Before the analysis, duplicated haplotypes were removed 267 from the data set using DnaSP v6.12.03 (Rozas et al. 2017). Branch lengths were estimated under a relaxed log-normal clock using the Bayesian analysis implemented in BEAST v1.10.4 (Suchard et al. 2018). A coalescent (constant size) prior was used and Markov Chains Monte Carlo (MCMC) were run for 20 million generations. Trees were sampled each 1,000 generations with a $10 \%$

272 burn-in. A visual inspection of MCMC progression using Tracer v1.7.1 (Rambaut 273 et al. 2018) was performed to corroborate stabilization. An ultrametric tree was constructed using Tree Annotator v1.10.4 (Rambaut \& Drummond 2018). Since the multiple-thresholds approach tends to overestimate the number of delineated species (Fujisawa \& Barraclough 2013) only the single-threshold (Pons et al. 
277 2006) versions of GMYC was fitted on the ultrametric tree using the SPLITS v1.0-

27819 package for R (https://r-forge.r-project.org/projects/splits/).

279279

280 Genetic diversity, network reconstruction and historical demography

281 Within each genetic species, defined using ABGD and GMYC, four diversity 282 indices were calculated for the 5P-COI gene using DnaSP v6.12.03 (Rozas et al. 283 2017): the number of haplotypes $(\mathrm{nH})$, the number of polymorphic sites (S), gene 284 diversity (H, Nei 1987) and nucleotide diversity (m, Nei \& Li 1979). Moreover, within each genetic species, haplotype networks were reconstructed for the 5P-

286 COI using the median-joining algorithm implemented in NETWORK v10.1.0.0 287 (Bandelt et al. 1999).

288 Finally, to evaluate changes in the demographic history of the genetic species, two complementary approaches were used to infer the historical demography using the 5P-COI dataset. First, Tajima's D (Tajima 1989) and Fu's Fs (Fu 1997) statistics were calculated to detect significant past changes in population size. Significant departure from selection-drift equilibrium was tested using 1,000 bootstrap replicates in Arlequin v3.5.2.2 (Excoffier \& Lischer 2010). Under the presumption of neutrality, negative values distinguish populations in expansion while positive values, associated to the loss of rare alleles, are considered as signature of recent bottleneck (Tajima 1989; Fu 1997). Second, the observed mismatch distributions of the number of differences between pairs of 5P-COI sequences were compared to estimated values under a model of demographic expansion (Roger \& Harpending 1992) using Arlequin v3.5.2.2 (Excoffier \& Lischer 2010). Multimodal distributions generally characterize populations in 
301 demographic equilibrium while unimodal distributions are associated with recent 302 expansion.

303303

RESULTS

305305

306

A total of 107 sequences of Plocamium spp. collected from 7 localities were

obtained for the 5P-COI (575bp; Table 1). Moreover, a sub sample of 18 and 5

308 individuals were sequenced for the $r b c L$ (641bp) and the LSU (2960bp),

309 respectively (Table 1 ). GenBank accession numbers for the three molecular

310 markers sequenced are available in the Supplementary Table 1.

311311

312 Phylogenetic relationships

313 Phylogenetic relationships based on 5P-COI, for both the $\mathrm{ML}$ and $\mathrm{BI}$ analyses,

314 recovered all specimens sequenced in the present study as a single, well-

315 supported monophyletic group, strongly divergent from all the other sequences

316 of Plocamium available in GenBank (Fig. 1). This Chilean clade appear as nested

317 within a poorly resolved group including most specimens sampled in Australia

318 and New Zealand, and as sister to a well-supported monophyletic group

319 composed by specimens of $P$. cartilagineum from New Zealand, $P$. patagiatum

320 J.Agardh from Australia and P. angustum from Australia and New Zealand (Fig.

321 1). It is interesting to note that specimens sampled within the same ocean tend

322 to be genetically related (Fig. 1). The Chilean clade was also recovered as sister

323 of South Hemisphere Plocamium species for the rbcL (i.e., as sister to KC174809, 
U21703, U26821 and HQ224543 from New Zealand, Fig. S1) and for the LSU

325 (as sister to AY881712 and AY881714 from Australia, Fig. S2). Finally, Chilean

326 sequences from the present study form three monophyletic lineages observed for

327 the three genetic markers used (Fig. 1, Fig. S1, Fig. S2). Whatever the gene 328 under study, these lineages were generally well supported for both the ML and 329 Bl analyses (Fig. 1, Fig. S1, Fig. S2).

Species delimitation

332 Genetic pairwise K2P distances for the 5P-COI ranged from 0 to 0.062 and the 333 ABGD located the barcode gap within the $0.010-0.030$ distance range (Fig. S3b). 334 Primary partitions using this threshold suggested the existence of three genetic 335 groups (Fig. 2, Fig. S3a). The likelihood of the GMYC model for the single 336 threshold model was (LGMYCsingle $=44.04$ ); a value significantly higher than 337 the one obtained for the null model ( $\mathrm{LO}=40.86)$. The number of partitions obtained for the GMYC was three, with confidence limits of three to five (Fig. 2, Fig. S4). The three monophyletic groups recovered using phylogenetic reconstructions (Fig. 1, S1 and S2) were supported as putative species by both the ABGD and the GMYC single-threshold results (Fig. 2). Moreover, values of Kimura 2-parameter (K2P) were more than ten times higher when measured between genetic species (Plocamium sp. 1 - Plocamium sp. $2=0.05361 \pm$ 0.00936; Plocamium sp. 1 - Plocamium sp. $3=0.03063 \pm 0.00684 ;$ Plocamium sp. 2 - Plocamium sp. $3=0.04652 \pm 0.00865)$ than between haplotypes sequenced within a single genetic species (within Plocamium sp. $1=0.00019 \pm$ 0.00019 ; within Plocamium sp. $2=0.00040 \pm 0.00014$; within Plocamium sp. $3=$ $0.00144 \pm 0.00079)$. The three putative genetic species of Plocamium from 
southern Chile were then named Plocamium sp. 1, Plocamium sp. 2 and

350 Plocamium sp. 3. Plocamium sp. 1 was restricted to Punta Guabún, the only locality sampled north of the $42^{\circ} S$ in the present study, while the two other species were distributed in sympatry in southern Chile (Fig. 3). The two species Plocamium sp. 2 and Plocamium sp. 3 were collected at the same sites in both intertidal (i.e., Los Canelos and Fiordo Yendegaia) and subtidal (i.e., San Gregorio, Faro Porvenir and Faro San Isidro) (Fig. 3). The 19 samples from Parque Chabunco were identified as Plocamium sp. 3.

Genetic diversity, haplotype network and demographic history.

For the 5P-COI data set the number of haplotypes $(\mathrm{nH})$ and number of polymorphic sites (S) were the lowest in Plocamium sp. $1(\mathrm{nH}=2 ; \mathrm{S}=1)$ and the highest in Plocamium sp. $3(\mathrm{nH}=6 ; \mathrm{S}=6$; Table 2). The highest values of genetic and nucleotide diversity were encountered in Plocamium sp. $2(\mathrm{H}=0.684 \pm 0.099$ and $\pi=0.00144 \pm 0.00111)$, while the lowest values were encountered in Plocamium sp. $1(\mathrm{H}=0.118 \pm 0.101$ and $\pi=0.00019 \pm 0.00048)$ (Table 2). Plocamium sp. 2 presented a haplotype network slightly more reticulated than the two other species, for which star-like type of networks were observed (Fig. 3). In the haplotype network Plocamium sp. 2 was connected to Plocamium sp. 3 by 25 mutational steps, while Plocamium sp. 1 was connected to Plocamium sp. 2 by 18 mutational steps. Whatever the species under study, all values of Tajima's D and Fu's Fs statistics were negative, but these were significant only for Plocamium sp. 3 (Table 3). Mismatch distributions were unimodal with the most commonly calculated number of differences between pairs of sequences equal to 0 in Plocamium sp. 1 and Plocamium sp. 3 and to 1 in Plocamium sp. 2 (Fig. 
4). Tests for goodness-of-fit based on the sum of square deviations (SSD) for the demographic expansion model give values ranking from 0.00012 ( $p$-value $=$ $0.38400)$ for Plocamium sp. 1 and 0.00028 ( $p$-value $=0.34400)$ for Plocamium sp. 3 up to 0.01945 (p-value $=0.23400)$ for Plocamium sp. 2 (Table 3). These results did not reject the null hypothesis of a population expansion in any of the three genetic species studied.

\section{DISCUSSION}

Our study revealed the existence of three genetic species of Plocamium in southern Chile, with Plocamium sp. 2 and Plocamium sp. 3 located in sympatry in Patagonia and Tierra del Fuego while Plocamium sp. 1 was only encountered north of the biogeographical limit at $42^{\circ} \mathrm{S}$. Interestingly, phylogenetic analyses recovered the Chilean clade as sister to a well-supported monophyletic group composed by specimens from New Zealand and Australia, suggesting the occurrence of transoceanic dispersal in the past. On the other hand, various paraphyletic taxa were observed within Plocamium phylogenetic trees (e.g., $P$. cartilagineum, P. patagiatum, $P$. angustum, $P$. fimbriatum M.J.Wynne, $P$. violaceum and P. pacificum; Fig. 1), clearly pointing out the difficulty of species identification based on morphological characters in this genus (Cremades et al. 2011). Concordance across results obtained with different methods (here GMYC and $A B G D$ ) and monophyly recovered in trees reconstructed with unlinked markers are now widely acknowledged as suitable for genetic species delimitation (Carstens et al. 2013; Modica et al. 2014). Our results confirm the relevance of information obtained from molecular markers encompassing the three cell compartments (i.e., mitochondria, chloroplast and nucleus) to delimit 
species in the genus Plocamium and better estimate species diversity,

400 distribution and understand the evolutionary history in these highly

401 morphologically variable red algae.

402402

403 Transoceanic dispersal as potential origin of Chilean Plocamium species

404 ancestral clade

405

406

407

408

409

410

411

412

413

414

415

416

417

418

419

420

421

422

423

In the phylogenetic trees, the three Chilean Plocamium species formed a clade embedded in sequences from the Southern Hemisphere and genetically close to clades from New Zealand and Australia. We propose that the Chilean Plocamium clade has diverged from Australian or New Zealand colonists, after their arrival by rafting in Chile. Transoceanic dispersal has commonly been reported, especially in taxa with high capacity of dispersal, for example fish (Blower et al. 2012) or crustacea (Page et al. 2005). Recurrent dispersal, more than vicariance, has indeed been postulated to be the mechanism leading to the biogeographic patterns and disjunct species distributions observed nowadays in the Southern Ocean (Waters 2008; Fraser et al. 2013). The importance of transoceanic rafting is less recognized in marine species with limited dispersal capacity (i.e., lack of larvae or short lived propagules) even if recent studies have demonstrated that this mechanism, depending on the species physiological/reproductive tolerance, could be highly efficient, allowing rapid expansion of their distribution ranges (Thiel \& Gutow 2005a; 2005b; Fraser et al. 2011; Fraser et al. 2013; Waters et al. 2013; Guillemin et al. 2014; Guillemin et al. 2016; Tala et al. 2019). In the Southern Hemisphere, currents are dominated by the Antarctic Circumpolar Current (ACC) and the West Wind Drift (WWD) (Waters 2008). Recurrent dispersal from Australia and/or New Zealand to Chile have been registered using 
molecular data in various macroalgae including the buoyant seaweed Durvillaea antarctica (Chamisso) Hariot (Fraser et al. 2009), but also the non-buoyant species Bostrychia intricata (Bory) Montagne, Adenocystis utricularis (Bory) Skottsberg (Fraser et al. 2013), Capreolia implexa Guiry \& Womersley (Boo et al. 2014) and Agarophyton chilense (C.J.Bird, McLachlan \& E.C.Oliveira) Gurgel, J.N.Norris et Fredericq (as Gracilaria chilensis C.J.Bird, McLachlan \& E.C.Oliveira; Guillemin et al. 2014). All these species show genetic signatures of recent west to east dispersal across vast oceanic distances. In the case of the genus Durvillaea Bory there is evidence of a long-distance dispersal event from New Zealand to temperate Chile that was followed by genetic divergence leading to the speciation of $D$. incurvata (Suhr) Macaya (a species restricted to Chilean temperate waters) some 3 - 10 Million years ago (Fraser et al. 2013; Fraser et al. 2019). Studies in other organisms, as in the coastal sac spiders of the genus Amaurobioides O. Pickard-Cambridge, show repeated events of long-distance dispersal along the WWD followed by divergence, revealing a remarkable pattern of "stepping-stone" speciation all around the Southern Ocean (Ceccarelli et al. 2016).

Speciation in the genus Plocamium along the coast of southern Chile

After transpacific colonization, distinct processes of divergence seem to have taken place during the radiation of the genetic Chilean Plocamium species ancestral clade. The species Plocamium sp. 1 is found isolated north of the biogeographical limit of $42^{\circ} \mathrm{S}$ and we propose that parapatric or allopatric speciation could have taken place in this case. A strong biogeographic discontinuity has been described at $41-42^{\circ} \mathrm{S}$ (Camus 2001), generally related to 
449 the latitudinal migration of the southern Westerlies during the Miocene450 Pleistocene. The split of the WWD into the northward Humboldt Current and the southward Cape Horn Current, located at these latitudes, has been demonstrated to represent a major oceanic barrier that has contributed to the origin of the biogeographic break. Nowadays, contrasted ecologic, climatic and topographic features characterize both sides of the $41-42^{\circ} \mathrm{S}$ biogeographical limit (Camus 2001). In the past, major currents restricting gene flow could have led to the divergence of Plocamium sp. 1 from Plocamium sp. 2 and 3; while more subtle differences in term of coastal topography or salinity could also help in maintaining these species genetic integrity nowadays. Our sampling does not allow separation of patterns of allopatric from parapatric speciation nor to precisely pinpoint the phylogeographic break in Plocamium (i.e., the gap between IA and MP sampling sites span more than 1,200 kilometers). However, other genetic studies described a phylogeographic break at the $41^{\circ} \mathrm{S}-42^{\circ} \mathrm{S}$ zone or nearby (the buoyant kelps Durvillaea spp., Fraser et al. 2010; in the brooding gastropod, Acanthina monodon, Sánchez et al. 2011; the Patagonian otter Lontra provocax, Vianna et al. 2011). Theoretical studies emphasize the possible quick genetic divergence that could be observed in scenarios of parapatric speciation in organisms with low dispersal capacity, as is the case for Plocamium, (Gravilets et al. 2000; Kuo \& Avise 2005). Moreover, parapatric speciation has been suggested as a common mechanism of speciation in macroalgae along the Chilean coast (brown algae: Lessonia trabeculata Villouta \& Santelices and L. 471 spicata (Suhr) Santelices, as L. nigrescens Bory in Tellier et al. 2009; red alga: 472 Mazzaella laminarioides (Bory) Fredericq, Montecinos et al. 2012). 
473 Contrasting with Plocamium sp. 1, the species Plocamium sp. 2 and 3 were in 474 sympatry in most localities sampled in Patagonia and Tierra del Fuego. Existence of cryptic genetic species or diverged haplotypic groups distributed in sympatry in southern Chile have already been reported in three macroalgae: Adenocystis utricularis, Bostrychia intricata (Fraser et al. 2013) and Iridaea cordata (Turner) Bory (Ocaranza et al. 2019). In these cases, divergence in sympatry or microallopatry could be hypothesized. Exhaustive surveys have revealed common patterns of genetic divergence, consistent with isolation in refugia during glacial periods, in various organisms (Hewitt 2004; Sérsic et al. 2011). During the Pleistocene glacial/interglacial cycles populations of temperate species could have survived in isolated microrefugia in Patagonia and Tierra del Fuego (for example, terrestrial organisms: Sérsic et al. 2011; freshwater fish: Zemlak et al. 2010). In the region, during the glacial maxima, Plocamium populations could have survived in small pockets of suitable habitat located at the edge of, or even within, glaciated areas (Rull 2009; Mosblech et al. 2011). During isolation periods (i.e., glacial maxima), divergence between microrefugia could be favored by drift and/or selection. After interglacial expansion from refugia, differentiated genetic groups or species (e.g., Plocamium sp. 2 and 3) could then be observed in sympatry in localities where secondary contact takes place (Zemlak et al. 2008; Zhang et al. 2008; Durand et al. 2009). Supporting the impact of glacial/interglacial cycles on marine Chilean species living at high latitude, our results suggest that both Plocamium sp. 2 and 3 have been affected by these cycles but that the bottleneck and demographic expansion is more recent in Plocamium sp. 3 (i.e., bottleneck probably linked to the LGM) than in Plocamium sp. 2. Strong ice impact during the LGM and recent demographic expansion has 
also been observed in other Patagonian macroalgae as Mazzaella laminarioides

499 (Montecinos et al. 2012), Gigartina skottsbergii Setchell \& N.L.Gardner (Billard et al. 2015) and Durvillaea antarctica (Fraser et al. 2009).

Various cryptic species, incorrectly named $P$. cartilagineum using morphological characters, are present in distinct parts of the Southern Hemisphere. One interesting example is the presence of $P$. cartilagineum sequences from individuals collected in Antarctica forming a genetic group fairly distinct from Plocamium sp. 1, 2 and 3 from Chile (see Fig. 1). Similar results were obtained for Iridaea cordata (Ocaranza et al. 2019) and Gigartina skottsbergii (Billard et al. 2015), where cryptic sister species were encountered on both side of the Drake Passage. The main difference between Plocamium and Iridaea cordata and Gigartina skottsbergii is that Antarctic and Chilean species are not sisterspecies in the case of Plocamium. Complex patterns of long distance colonization followed by speciation seem to characterize Southern Hemisphere macroalgae; with some colonization routes following the main currents (ACC and WWD; Durvillaea: Fraser et al. 2019; Trematocarpus Kützing and Mazzaella G.De Toni f.: Hommersand \& Fredericq 2003; Plocamium: present study) and some crossing them (ACC; Iridaea cordata and Gigartina skottsbergii: Hommersand \& Fredericq 2003; Billard et al. 2015; Ocaranza et al. 2019). More efforts are needed to understand the evolutionary history of Plocamium in the Southern Hemisphere including the sub-Antarctic Islands and the coasts of the Antarctic Peninsula. Moreover, further work increasing the number of sites sampled (especially in the PP and the IA) could help to better understand Plocamium species diversity in Chile and to study speciation processes in this ecologically important group of red algae. 
525 This study was supported by the INACH project RG_15-16 and the FONDAP 526 program project no. 15150003 (FONDAP IDEAL). OH is supported by BECA DE 527 DOCTORADO NACIONAL Grant\#21120791 (CONICYT, Chile). The authors are 528 grateful to Sylvain Faugeron and his team for sample collection in Punta Guabún, 529 Erasmo Macaya for sample collection in Fiordo Yendegaia, Mateo Caceres and 530 Diego Bravo for their help in the field in Patagonia and Tierra del Fuego, and 531 Kamilla Flores Robles and Hardy Guzman for lab support. We would like to thank 532 the two reviewers for their comments and efforts towards improving our 533 manuscript. We also thank the IDEAL staff for assistance with infrastructure, 534 especially in Punta Arenas.

535535

536 DATA SHARING AND DATA ACCESSIBILITY

537 The authors confirm that all data underlying the findings are fully available without 538 restriction. All sequences are available in GenBank (accession numbers in 539 Supplementary Table 1).

540540

541 COMPETING INTEREST

542 The authors declare that they have no competing interests. 
MLG conceived the study. AEM and $\mathrm{ORH}$ generated molecular data sets. AEM

manuscript. MER deposited the individuals into the museum (SGO) and obtained manuscript.

\section{REFERENCES}

ALVES C., PINTEUS S., RODRIGUES A., HORTA A. \& PEDROSA R. 2018. 48. 
BILLARD E., REYES J., MANSILLA A., FAUGERON S. \& GUILLEMIN M.-L. 2015. - Deep genetic divergence between austral populations of the red alga Gigartina skottsbergii reveals a cryptic species endemic to the Antarctic continent. Polar Biology 38: 2021-2034.

BISCHOFF-BÄSMANN B. \& WIENCKE C. 1996. - Temperature requirements for growth and survival of Antarctic Rhodophyta. Journal of Phycology 32: 525-535.

BLOWER D. C., PANDOLFI J. M., BRUCE B. D., GOMEZ-CABRERA M. C. \& OVENDEN J. R. 2012. - Population genetics of Australian white sharks reveals fine-scale spatial structure, transoceanic dispersal events and low effective population sizes. Marine Ecology Progress Series 455: 229-244.

BOO G. H., MANSILLA A., NELSON W., BELLGROVE A. \& BOO S. M. 2014. Genetic connectivity between transoceanic populations of Capreolia implexa (Gelidiales, Rhodophyta) in cool temperate waters of Australasia and Chile. Aquatic Botany 119: 73-79.

CALEGARIO G., FREITAS L., SANTOS E., SILVA B., OLIVEIRA L., GARCIA G., OMACHI C., PEREIRA R., THOMPSON C. \& THOMPSON F. 2019. Environmental modulation of the proteomic profiles from closely phylogenetically related populations of the red seaweed Plocamium brasiliense. PeerJ 7: e6469.

CAMUS P. 2001. - Biogeografía marina de Chile continental. Revista Chilena de Historia Natural 74: 587-617.

CARSTENS B. C., PELLETIER T. A., REID N. M. \& SATLER J. D. 2013. — How to fail at species delimitation. Molecular Ecology 22: 4369-4383. 
CECCARELLI S. F., OPELL B. D., HADDAD C. R., RAVEN R. J., SOTO E. M. \& RAMIREZ M. J. 2016. - Around the world in eight million years: Historical biogeography and evolution of the spray zone spider Amaurobioides (Araneae: Anyphaenidae). PLOS ONE 11 (10): e0163740.

CREMADES J., BARREIRO R., MANEIRO I. \& SAUNDERS G. W. 2011. - A new taxonomic interpretation of the type of Plocamium cartilagineum (Plocamiales, Florideophyceae) and its consequences. European Journal of Phycology 46 (2): 125-142.

DAWSON M. N. 2001. - Phylogeography in coastal marine animals: a solution from California? Journal of Biogeography 28: 723-736.

DE QUEIROZ K. 1998. — The general lineage concept of species, species criteria, and the process of speciation: A conceptual unification and terminological recommendations, in Howard D. J. and Berlocher, S. H. (eds.), Endless forms: Species and speciation. Oxford University Press, Oxford: 5775.

DUBRASQUET H., REYES J., SANCHEZ R. P., VALDIVIA N. \& GUILLEMIN M.L. 2018. - Molecular-assisted revision of red macroalgal diversity and distribution along the Western Antarctic Peninsula and South Shetland Islands. Cryptogamie Algologie 39 (4): 409-429.

DURAND E., JAY F., GAGGIOTTI O. E. \& FRANCOIS O. 2009. - Spatial inference of admixture proportions and secondary contact zones. Molecular Biology and Evolution 26: 1963-1973. 
614 ETCHEVERRY H. 1986. - Algas marinas bentónicas de Chile. UNESCO,

615 Regional office of Science and Technology for Latin America and the

616 Caribbean. Montevideo, Uruguay, 381p.

617 EXCOFFIER L. \& LISHER H. 2010. - Arlequin suite ver 3.5: a new series of

618 programs to perform population genetics analyses under Linux and Windows.

619 Molecular Ecology Resources 10: 56.

620 FRASER C. I., NIKULA R., SPENCER H. G. \& WATERS J. M. 2009. - Kelp

621 genes reveal effects of subantarctic sea ice during the Last Glacial

622 Maximum. Proceedings of the National Academy of Sciences of USA 106:

$623 \quad 3249-3253$.

624

625

626

627

628

629

630

631

632

633

634

FRASER C. I., THIEL M., SPENCER H. G. \& WATERS J. M. 2010. —

Contemporary habitat discontinuity and historic glacial ice drive genetic divergence in Chilean kelp. BMC Evolutionary Biology 10: 203.

FRASER C. I., NIKULA R. \& WATERS J. M. 2011. — Oceanic rafting by a coastal community. Proceedings of the Royal Society of London Series B: Biological Sciences 278: 649-655.

FRASER C. I., ZUCCARELLO G. C., SPENCER H. G., SALVATORE L. C., GARCIA G. R. \& WATERS J. M. 2013. - Genetic affinities between transoceanic populations of non-buoyant macroalgae in the high latitudes of the Southern Hemisphere. PloS ONE 8 (7): e69138.

FRASER C. I., VELÁSQUEZ M., NELSON W., MACAYA E. \& CAMERON H. H. 2019. - The biogeographic importance of buoyancy in macroalgae: A case study of the southern bull kelp genus Durvillaea (Phaeophyceae), including descriptions of two new species. Journal of Phycology 56: 23-36. 
FU Y.-X. 1997. - Statistical tests of neutrality of mutations against population growth, hitchhiking and background selection. Genetics 147: 915-925.

FUJISAWA T. \& BARRACLOUGH T. G. 2013. - Delimiting species using singlelocus data and the Generalized Mixed Yule Coalescent (GMYC) approach: A revised method and evaluation on simulated datasets. Systematic Biology 62: 707-724.

GABRIELSON P. W. \& SCAGEL R. F. 1989. - The marine algae of British Columbia, northern Washington and Southeast Alaska: division Rhodophyta (red algae), class Rhodophyceae, order Gigartinales, families Caulacanthaceae and Plocamiaceae. Canadian Journal of Botany 67:12211234.

GRAVILETS S., LI H. \& VOSE M. D. 2000. — Patterns of parapatric speciation. Evolution 54: 1126-1134.

GRESSLER V., FUJII M. T., MARTINS A. P., COLEPICOLO P., MANCINI-FILHO J. \& PINTO E. 2011. - Biochemical composition of two red seaweed species grown on the Brazilian coast. Journal of the Science of Food and Agriculture 91 (9): 1687-1692.

GUILLEMIN M.-L., VALERO M., FAUGERON S., NELSON W. \& DESTOMBE C. 2014. - Tracing the trans-pacific evolutionary history of a domesticated seaweed (Gracilaria chilensis) with archaeological and genetic data. PLoS ONE 9 (12): e114039.

GUILLEMIN M.-L., VALERO M., TELLIER F., MACAYA E. C., DESTOMBE C. \& FAUGERON S. 2016. - Phylogeography of seaweeds in the South East Pacific: Complex evolutionary processes along a latitudinal gradient, in $\mathrm{Hu}$ 
Z.-M. \& Fraser C. I (eds.), Seaweed Phylogeography. Springer, Dordrecht: 251-278.

664

665

666

667

668

669

670

671

672

673

674

675

676

677

678

679

680

681

682

683

684

GUIRY M. D. \& GUIRY G. M. 2020. — AlgaeBase, Worldwide electronic publication, National University of Ireland, Galway. Available at http://www.algaebase.org.

HARPER J. T. \& SAUNDERS G. W. 2001. - The application of sequences of the ribosomal cistron to the systematics and classification of the florideophyte red algae (Florideophyceae Rhodophyta). Cahiers de Biologie Marine 42: 2538.

HAYE P. A., SEGOVIA N. I., MUÑOZ-HERRERA N. C., GÁLVEZ F. E., MARTíNEZ A., MEYNARD A., PARDO-GANDARILLAS M. C., POULIN E. \& FAUGERON S. 2014. - Phylogeographic structure in benthic marine invertebrates of the southeast Pacific coast of Chile with differing dispersal potential. PLOS ONE 9 (2): e88613.

HEWITT G. 2004. - Genetic consequences of climatic oscillations in the Quaternary. Philosophical Transactions of the Royal Society of London B: Biological Sciences 359: 183-195.

HOMMERSAND M. H., FREDERICQ S. \& FRESHWATER D. W. 1994. Phylogenetic systematics and biogeography of the Gigartinaceae (Gigartinales Rhodophyta) based on sequence-analysis of rbcL. Botanica Marina 37: 193-203.

HOMMERSAND M. H. \& FREDERICQ S. 2003. - Biogeography of the marine red algae of the South African West Coast: a molecular 
approach. Proceedings of the International Seaweed Symposium 17: 325336.

687

688

689

690

691

692

HULTON N. R. J., PURVES R. S., MCCULLOCH R. D., SUGDEN D. E. \& BENTLEY M. J. 2002. - The Last Glacial Maximum and deglaciation in southern South America. Quaternary Science Reviews 21: 233-241.

HURT C., ANKER A. \& KNOWLTON N. 2009. - A multilocus test of simultaneous divergence across the Isthmus of Panama using snapping shrimp in the genus Alpheus. Evolution 63: 514-530.

KALYAANAMOORTHY S., MINH B. Q., WONG T. K. F., VON HAESELER A. \& JERMIIN L. S. 2017. — ModelFinder: fast model selection for accurate phylogenetic estimates. Nature Methods 14: 587.

KELLY R. P. \& PALUMBI S. R. 2010. - Genetic structure among 50 species of the Northeastern Pacific rocky intertidal community. PLOS ONE 5: e8594.

KUMAR S., STECHER G., LI M., KNYAZ C. \& TAMURA K. 2018. — MEGA X: Molecular Evolutionary Genetics Analysis across Computing Platforms. Molecular Biology and Evolution 35 (6): 1547-1549.

KUO C. H. \& AVISE J. C. 2005. - Phylogeographic breaks in low-dispersal species: the emergence of concordance among gene trees. Genetica 124: 179-186.

MCCULLOCH R. D., BENTLEY M. J., PURVES R. S., HULTON N. R. J., SUGDEN D. E. \& CLAPPERTON C. M. 2000. - Climatic inferences from glacial and palaeoecological evidence at the last glacial termination, southern South America. Journal of Quaternary Science 15: 409-417. 
MERCER J. 1976. — Glacial history of Southernmost South America. Quaternary Research 6 (2): 125-166.

MODICA M. V., PUILLANDRE N., CASTELIN M., ZHANG Y. \& HOLFORD M. 2014. - A good compromise: Rapid and robust species proxies for inventorying biodiversity hotspots using the Terebridae (Gastropoda: Conoidea). PLOS ONE 9: e102160.

MONAGHAN M. T., WILD R., ELLIOT M., FUJISAWA T., BALKE M., INWARD D. J. G., LEES D. C., RANAIVOSOLO R., EGGLETON P., BARRACLOUGH T. G. \& VOGLER A. P. 2009. - Accelerated species inventory on Madagascar using coalescent-based models of species delineation. Systematic Biology 58: 298-311.

MONTECINOS A., BROITMAN B. R., FAUGERON S., HAYE P., TELLIER F. \& GUILLEMIN M.-L. 2012. — Species replacement along a linear coastal habitat: phylogeography and speciation in the red alga Mazzaella laminarioides along the south east pacific. BMC Evolutionary Biology 12: 97.

MOSBLECH N. A., BUSH M. B. \& VAN WOESIK R. 2011. - On metapopulations and microrefugia: paleoecological insights. Journal of Biogeography 38: 419429.

NEI M. \& LI W. H. 1979. — Mathematical model for studying genetic variation in terms of restriction endonucleases. Proceedings of the National Academy of Sciences of the USA 76: 5260-5273.

NEI M. 1987. - Molecular Evolutionary Genetics. New York, United States, Columbia University Press, 512p. 
OCARANZA-BARRERA P., GONZALEZ-WEVAR C. A., GUILLEMIN M.-L., ROSENFELD S. \& MANSILLA A. 2019. - Molecular divergence between Iridaea cordata (Turner) Bory de Saint-Vincent from Antarctic Peninsula and the Magellan Region. Journal of Applied Phycology 31: 939-949.

PAGE T. J., BAKER A. M., COOK B. D. \& HUGHES J. M. 2005. - Historical transoceanic dispersal of a freshwater shrimp: the colonisation of the South Pacific by the genus Paratya (Atyidae). Journal of Biogeography 32: 581-593.

PEREIRA R. C. \& COSTA-LOTUFO L. V. 2012. - Bioprospecting for bioactives from seaweeds: potential, obstacles and alternatives. Revista Brasileira de Farmacognosia 22 (4): 894-905.

PEREIRA R. C. \& VASCONCELOS M. A. 2014. - Chemical defense in the red seaweed Plocamium brasiliense: spatial variability and differential action on herbivores. Brazilian Journal of Biology 74 (3): 545-552.

PONS J., BARRACLOUGH T. G., GOMEZ-ZURITA J., CARDOSO A., DURAN D. P., HAZELL S., KAMOUN S., SUMLIN W. D. \& VOGLER A. P. 2006. Sequence-based species delimitation for the DNA taxonomy of undescribed insects. Systematic Biology 55: 595-609.

PUILLANDRE N., LAMBERT A., BROUILLET S. \& ACHAZ G. 2012. — ABGD, Automatic Barcode Gap Discovery for primary species delimitation. Molecular Ecology 21: 1864-1877.

RAMBAUT A. \& DRUMMOND A. J. 2018. - TreeAnnotator version 1.10.4: MCMC Output analysis. Available at: https://beast.community/treeannotator. 
RAMBAUT A., DRUMMOND A. J., XIE D., BAELE G. \& SUCHARD M. A. 2018. _ Posterior summarisation in Bayesian phylogenetics using Tracer 1.7. Systematic Biology syy032.

RAMÍREZ M. E. \& SANTELICES B. 1991. - Catálogo de algas marinas bentónicas de la costa templada del Pacífico de Sudamérica. Pontificia Universidad Católica de Chile. Santiago, Chile, 430p.

RAMÍREZ M. E. 2010. — Flora marina bentónica de la región austral de Sudamérica y la Antártica. Anales Instituto Patagonia 38: (1): 57-71.

ROGER A. R. \& HARPENDING H. 1992. - Population growth makes waves in the distribution of pairwise genetic differences. Molecular Biology and Evolution 9: 552-569.

RONQUIST F., TESLENKO M., VAN DER MARK P., AYRES D. L., DARLING A., HÖHNA S., LARGET B., LIU L., SUCHARD M. A. \& HUELSENBECK J. P. 2012. - MRBAYES 3.2: Efficient Bayesian phylogenetic inference and model selection across a large model space. Systematic Biology 61: 539542.

ROZAS J., FERRER-MATA A., SÁNCHEZ-DELBARRIO J. C., GUIRAO-RICO S., LIBRADO P., RAMOS-ONSINS S. E. \& SÁNCHEZ-GRACIA A. 2017. DnaSP v6: DNA Sequence Polymorphism Analysis of Large Datasets. Molecular Biology and Evolution 34: 3299-3302.

RULL V. 2009. - Microrefugia. Journal of Biogeography 36: 481-484.

SAILLARD M., HALL S. R., AUDIN L., FARBER D. S., HÉRAL G., MARTINOD J., REGARD V., FINKEL R. C. \& BONDOUX F. 2009. — Non-steady long- 
term uplift rates and Pleistocene marine terrace development along the Andean margin of Chile $\left(31^{\circ} \mathrm{S}\right)$ inferred from ${ }^{10} \mathrm{Be}$ dating. Earth and Planetary Sciences Letters 277: 50-63.

SÁNCHEZ R., SEPÚLVEDA R. D., BRANTE A. \& CÁRDENAS L. 2011. — Spatial pattern of genetic and morphological diversity in the direct developer Acanthina monodon (Gastropoda: Mollusca). Marine Ecology Progress Series 434: 121-131.

SAN-MARTIN A., NEGRETE R. \& ROVIROSA J. 1991. — Insecticide and acaricide activities of polyhalogenated monoterpenes from Chilean Plocamium cartilagineum. Phytochemistry 30: 2165-2169.

SAUNDERS G. W. 2005. - Applying DNA barcoding to red macroalgae: a preliminary appraisal holds promise for future applications. Philosophical Transactions of the Royal Society of London B: Biological Sciences 360: 1879-1888.

SAUNDERS G. W. \& LEHMKUHL K. V. 2005. - Molecular divergence and morphological diversity among four cryptic species of Plocamium (Plocamiales, Florideophyceae) in northern Europe. European Journal of Phycology 40: 293-312.

SÉRSIC A. N., COSACOV A., COCUCCI A. A., JOHNSON L. A., POZNER R., AVILA L. J., SITES J. W. Jr \& MORANDO M. 2011. — Emerging phylogeographic patterns of plants and terrestrial vertebrates from Patagonia. Biological Journal of the Linnean Society 103: 475-494.

SIMONS R. H. 1964. - Species of Plocamium on the South African Coast. Bothalia 8: 183-193. 
SOUTH G. R. \& ADAMS N. M. 1979. - A revision of the genus Plocamium Lamouroux (Rhodophyta, Gigartinales) in New Zealand. Phycologia 18: 120132.

SUCHARD M. A., LEMEY P., BAELE G., AYRES D. L., DRUMMOND A. J. \& RAMBAUT A. 2018. - Bayesian phylogenetic and phylodynamic data integration using BEAST 1.10. Virus Evolution 4 (1): vey016.

TAJIMA F. 1989. - Statistical method for testing the neutral mutation hypothesis by DNA polymorphism. Genetics 123: 585-595.

TALA F., LOPEZ B. A., VELÁSQUEZ M., JELDRES R., MACAYA E. C., MANSILLA A., OJEDA J. \& THIEL M. 2019. — Long-term persistence of the floating bull kelp Durvillaea antarctica from the South-East Pacific: Potential contribution to local and transoceanic connectivity. Marine Environmental Research 149: 67-79.

TELLIER F., MEYNARD A. P., CORREA J. A., FAUGERON S. \& VALERO M. 2009. - Phylogeographic analyses of the $30^{\circ} \mathrm{S}$ south-east Pacific biogeographic transition zone establish the occurrence of a sharp genetic discontinuity in the kelp Lessonia nigrescens: Vicariance or parapatry? Molecular Phylogenetics and Evolution 53: 679-693.

THIEL M. \& GUTOW L. 2005a. - The ecology of rafting in the marine environment I. The floating substrata. Oceanography Marine Biology Annual Reviews 42: 181-263.

THIEL M. \& GUTOW L. 2005b. - The ecology of rafting in the marine environment II. The rafting organisms and community. Oceanography Marine Biology Annual Reviews 43: 279-418. 
TRIFINOPOULOS J., NGUYEN L.-T., VON HAESELER A. \& MINH B. Q. 2016. - W-IQ-TREE: a fast online phylogenetic tool for maximum likelihood analysis. Nucleic Acids Research 44: W232-W235.

VIANNA J. A., MEDINA-VOGEL G., CHEHÉBAR C., SIELFELD W., OLAVARRIA C. \& FAUGERON S. 2011. - Phylogeography of the Patagonian otter Lontra provocax: adaptive divergence to marine habitat or signature of southern glacial refugia? BMC Evolutionary Biology 11:53.

WATERS J. M. 2008. — Driven by the West Wind Drift? A synthesis of southern temperate marine biogeography, with new directions for dispersalism. Journal of Biogeography 35 (3): 417-427.

WATERS J. M., FRASER C. I. \& HEWITT G. M. 2013. - Founder takes all: density-dependent processes structure biodiversity. Trends in Ecology \& Evolution 28: 78-85.

WOMERSLEY H. B. S. 1971. - The genus Plocamium (Rhodophyta) in southern Australia. Transactions of The Royal Society of South Australia 95: 9-27.

WYNNE M. J. 2002. - A description of Plocamium fimbriatum sp. nov. (Plocamiales, Rhodophyta) from the Sultanate of Oman, with a census of currently recognized species in the genus. Nova Hedwigia 75: 333-356.

YANO T., KAMIYA M., ARAI S. \& KAWAI H. 2004. - Morphological homoplasy in Japanese Plocamium species (Plocamiales, Rhodophyta) inferred from the Rubisco spacer sequence and intracellular acidity. Phycologia 43: 383-393.

ZEMLAK T. S., HABIT E. M., WALDE S. J., BATTINI M. A., ADAMS E. D. \& RUZZANTE D. E. 2008. - Across the southern Andes on fin: glacial refugia, 
847 drainage reversals and a secondary contact zone revealed by the

848 phylogeographical signal of Galaxias platei in Patagonia. Molecular Ecology

$849 \quad 17: 5049-5061$.

850 ZEMLAK T. S., HABIT E. M., WALDE S. J., CARREA C. \& RUZZANTE D. E. 851 2010. - Surviving historical Patagonian landscapes and climate: molecular 852 insights from Galaxias maculatus. BMC Evolutionary Biology 10: 67.

853 ZHANG H., YAN J., ZHANG G. Q. \& ZHOU K. Y. 2008. - Phylogeography and 854 Demographic History of Chinese Black-Spotted Frog Populations 855 (Pelophylax nigromaculata): Evidence for Independent Refugia Expansion $856 \quad$ and Secondary Contact. BMC Evolutionary Biology 8: 21. 
860 Table 1 - Sampling localities and number of individuals sequenced for the three

861 molecular markers used in the present study. Abbreviation (CODE) and

862 geographic coordinates are indicated.

\begin{tabular}{lccccc}
\hline \multicolumn{1}{c}{ Locality } & CODE & Coordinates & 5 P-COI & $r b c L$ & LSU \\
\hline Punta Guabún & GUA & $41^{\circ} 38^{\prime} \mathrm{S} / 74^{\circ} 02^{\prime} \mathrm{W}$ & 17 & 6 & 2 \\
San Gregorio & GRE & $52^{\circ} 33^{\prime} \mathrm{S} / 70^{\circ} 02^{\prime} \mathrm{W}$ & 2 & - & - \\
Parque Chabunco & CHA & $52^{\circ} 59^{\prime} \mathrm{S} / 70^{\circ} 48^{\prime} \mathrm{W}$ & 19 & - & - \\
Faro Porvenir & POR & $53^{\circ} 18^{\prime} \mathrm{S} / 70^{\circ} 27^{\prime} \mathrm{W}$ & 18 & - & - \\
Los Canelos & CAN & $53^{\circ} 28^{\prime} \mathrm{S} / 70^{\circ} 11^{\prime} \mathrm{W}$ & 9 & 1 & 1 \\
Faro San Isidro & FSI & $53^{\circ} 46^{\prime} \mathrm{S} / 70^{\circ} 58^{\prime} \mathrm{W}$ & 24 & 2 & 1 \\
Fiordo Yendegaia & YEN & $54^{\circ} 54^{\prime} \mathrm{S} / 68^{\circ} 42^{\prime} \mathrm{W}$ & 18 & 9 & 1 \\
\hline & & TOTAL & 107 & 18 & 5 \\
\hline
\end{tabular}


865 Table 2 - Genetic diversity estimates for the molecular marker 5P-COI. Each 866 Plocamium genetic species, as delimited by ABGD and GMYC, was treated 867 separately.

\begin{tabular}{cccccccc}
\hline Species & $\mathrm{N}$ & $\mathrm{nH}$ & $\mathrm{H}$ & $\mathrm{SD}$ & $\pi$ & $\mathrm{SD}$ & $\mathrm{S}$ \\
\hline Plocamium sp. 1 & 17 & 2 & 0.118 & 0.101 & 0.00019 & 0.00048 & 1 \\
Plocamium sp. 2 & 17 & 5 & 0.684 & 0.099 & 0.00144 & 0.00111 & 4 \\
Plocamium sp. 3 & 73 & 6 & 0.133 & 0.054 & 0.00026 & 0.00093 & 6
\end{tabular}

\section{TOTAL 107}

$868 \mathrm{~N}$ : number of sequences; $\mathrm{nH}$ : number of haplotypes; $\mathrm{H}$ : gene diversity; $\pi$ : 869 nucleotide diversity; S: number of polymorphic sites; SD: Standard deviation. 
871 Table 3 - Neutrality tests calculated using the 5P-COI marker data set. Results

872 are given separately for each Plocamium genetic species (as delimited by ABGD 873 and GMYC).

874874

\begin{tabular}{ccccccc}
\hline Species & Tajima's D & p-value & Fu's Fs & p-value & SSD & $p$-value \\
\hline Plocamium sp. 1 & -1.16387 & 0.14500 & -0.74844 & 0.07800 & 0.00012 & 0.38400 \\
Plocamium sp. 2 & -0.74003 & 0.26300 & -1.61645 & 0.08000 & 0.01945 & 0.23400 \\
Plocamium sp. 3 & -2.16969 & 0.00000 & -7.46656 & 0.00000 & 0.00028 & 0.34400
\end{tabular}

SSD: Sum of square deviations. 


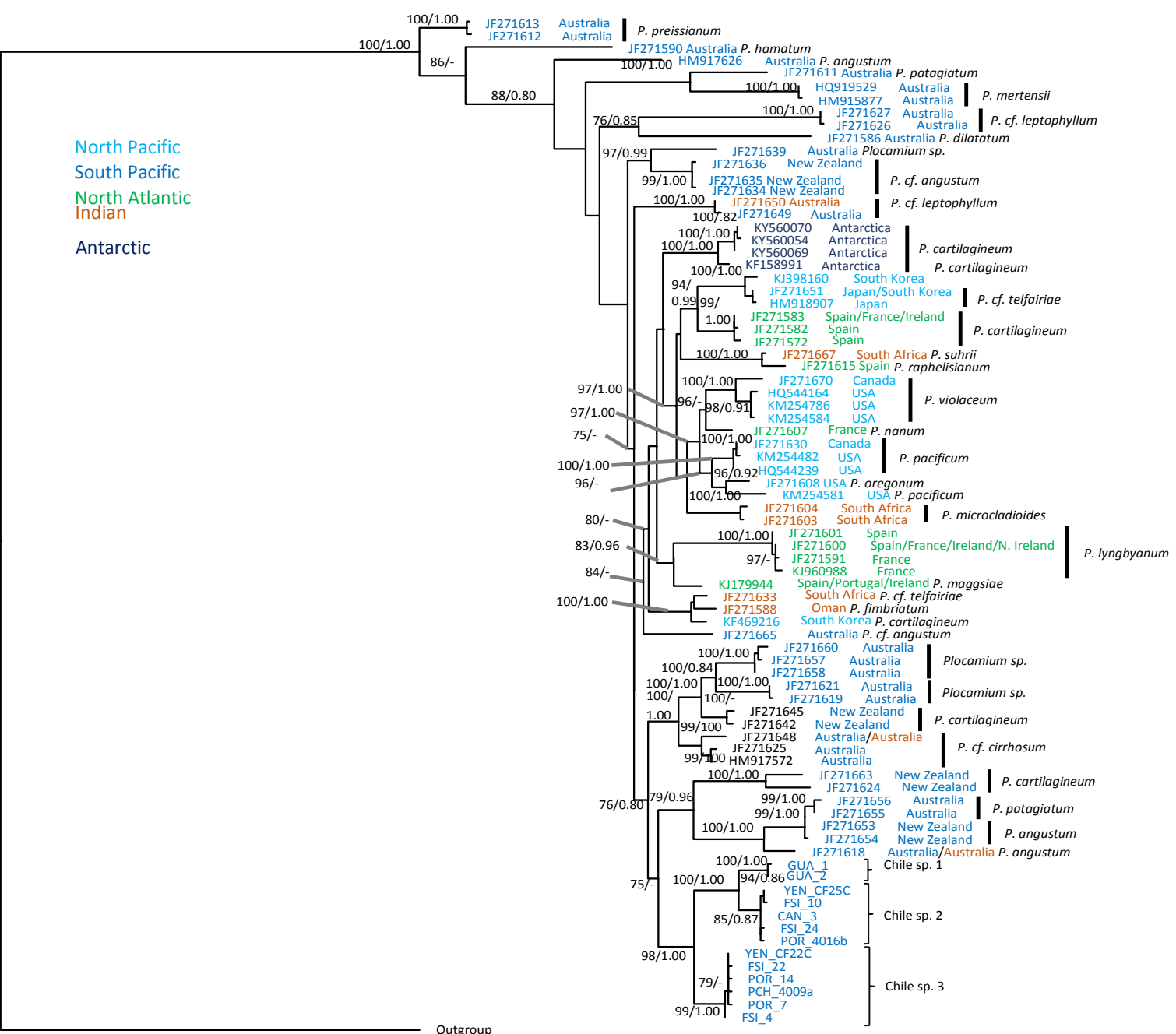

878 Figure 1 - Maximum likelihood (ML) phylogram of the genus Plocamium based 879 on 5P-COI sequences. ML bootstrap (BS)/Bayesian posterior probability (PP) 880 values are shown above each branch and only values superior to 75 and 0.75 , 881 respectively, are given. Colors correspond to oceans where individuals 882 sequenced where sampled. Species names, as reported in GenBank, are given 883 on the right. Outgroup corresponds to Asparagopsis armata (GenBank 884 accession: KJ960344). 


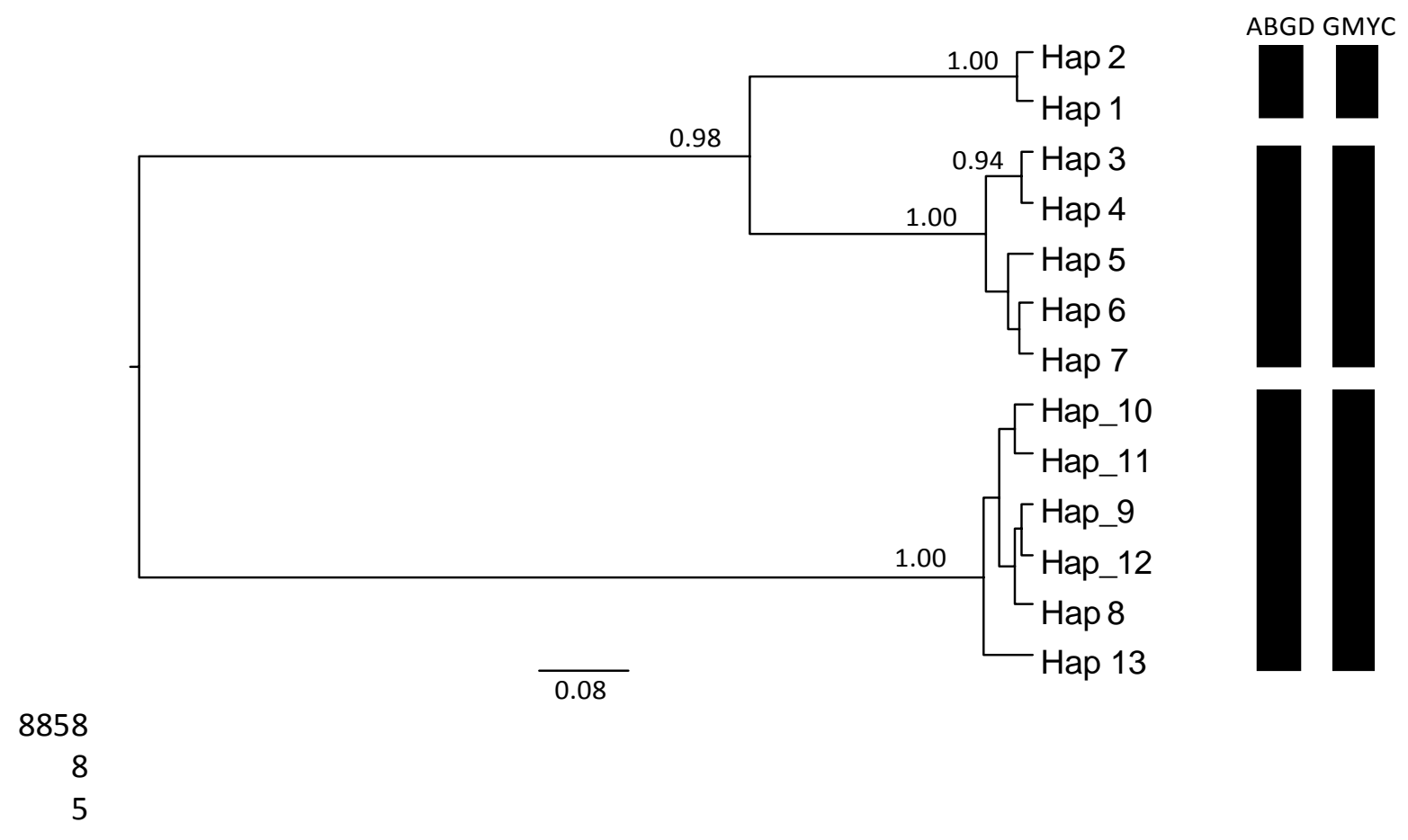

886 Figure 2 - Bayesian inference ultrametric gene tree (5P-COI). Species 887 delimitation results from $A B G D$ and GMYC are given on the right. Only distinct 888 haplotypes sequenced during the present study are represented. Haplotype code 889 as in Supplementary Table 1.

890890 
891891

892892

893893

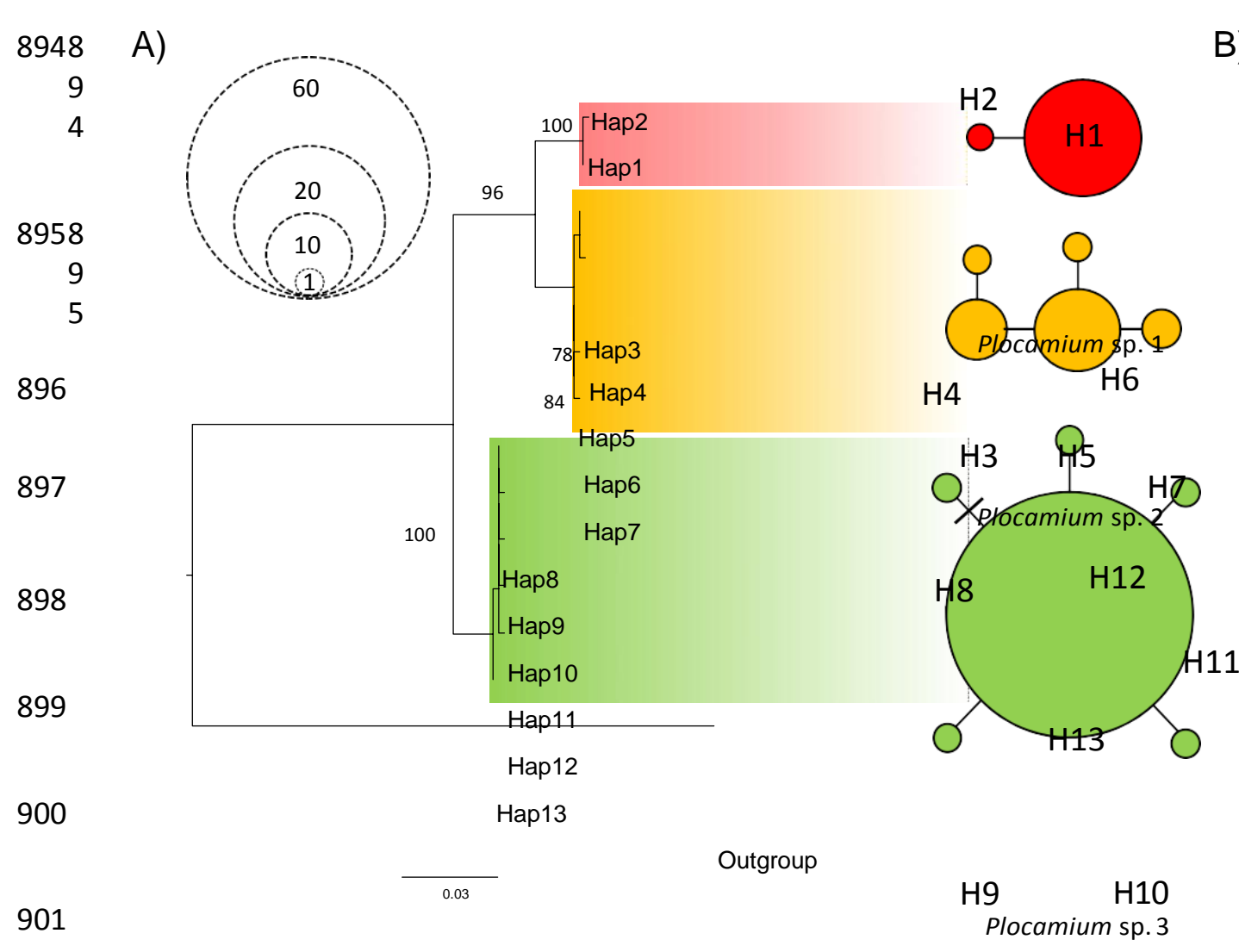

GUA

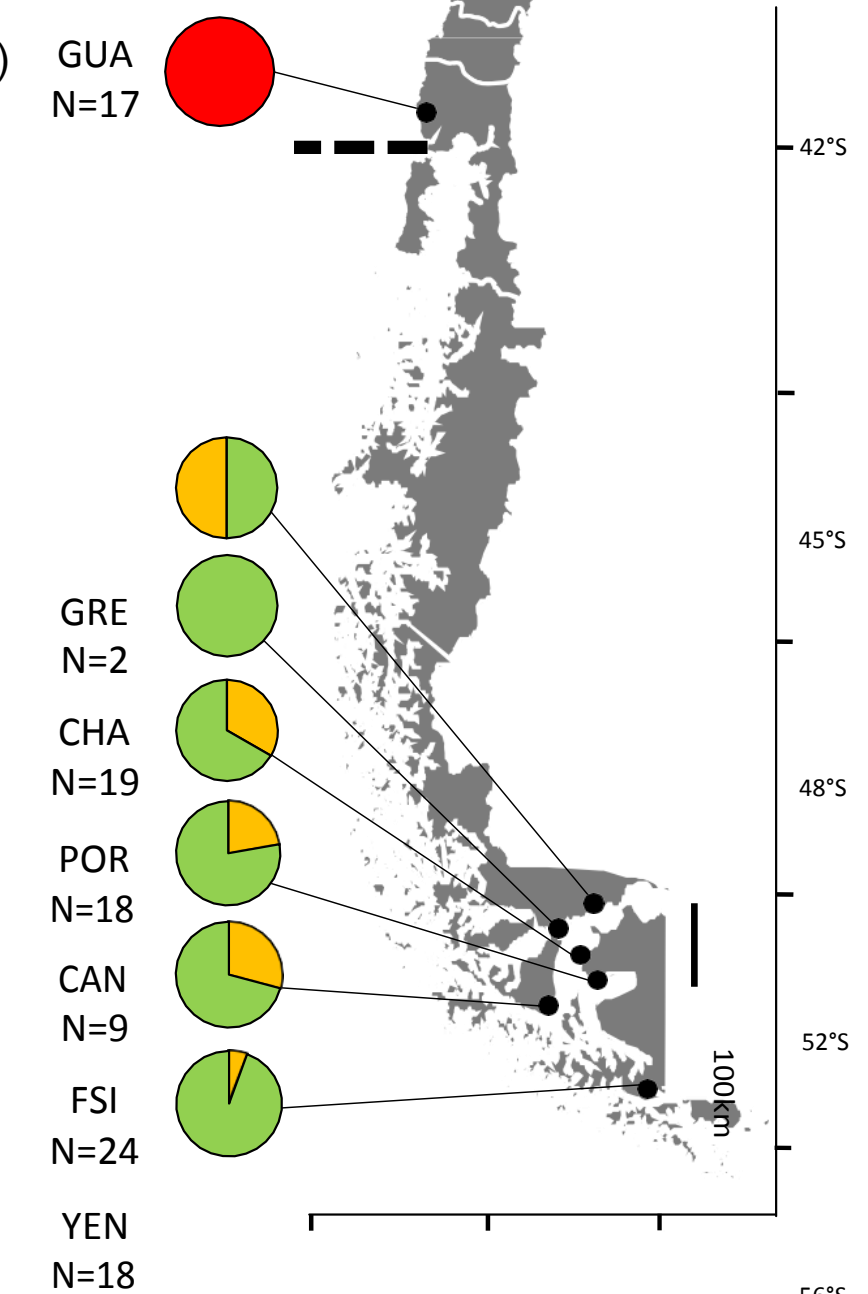


904 Figure $3-\mathrm{A}$ ) ML tree (left) and Neighbour joining (NJ) network (right) inferred from 5P-COI sequences dataset of Plocamium 905 specimens from the present study. In the tree, numbers above the branches are support values as inferred from ML analysis, 906 only values superior to 75 are given. In the NJ networks, haplotypes are represented by open circles with size proportional 907 to frequency within each genetic species (see upper left corner for correspondence between number of sequences and 908 circle size). For haplotypes separated by more than one mutational step, black bars indicate the additional number of steps. 909 B) Plocamium species distribution; the number $(\mathrm{N})$ of individuals sequenced is indicated for each sampling locality. Code for 910 each locality as in Table 1; haplotype code as in Supplementary Table 1. Dashed line represents the biogeographic transition 911 zone located at $42^{\circ} \mathrm{S}$. 

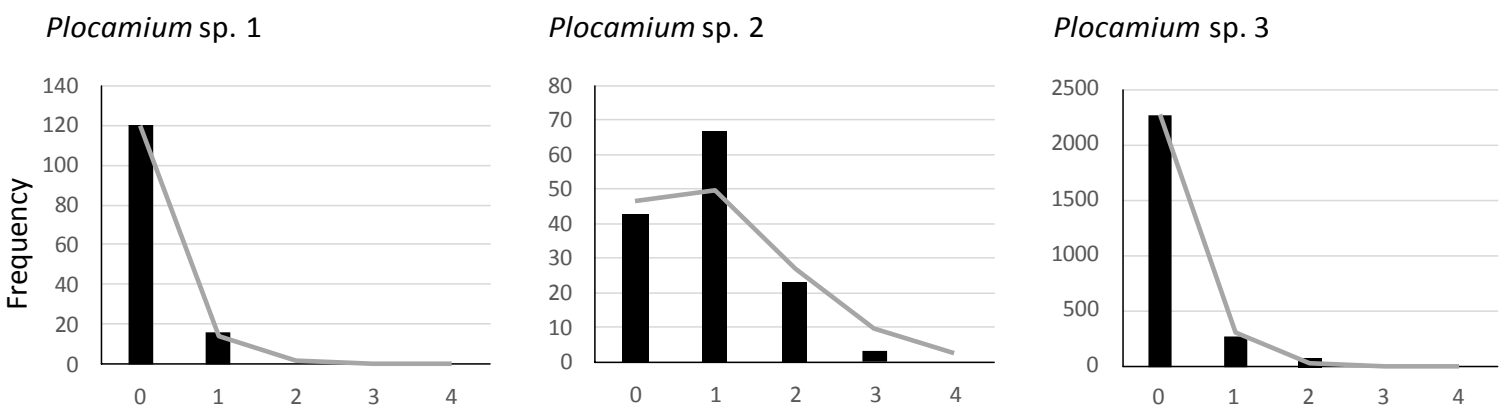

9139

Number of pairwise differences

915 Figure 4 - Mismatch distributions calculated for the 5P-COI data set; each 916 Plocamium genetic species (as delimited by ABGD and GMYC) was treated 917 separately. Observed distributions (black histograms) and expected distributions 918 under a model of demographic expansion (grey lines) of the number of pair base 919 differences between sequences of 5P-COI. 
North Pacific

South Pacific

North Atlantic

Indian

Antarctic

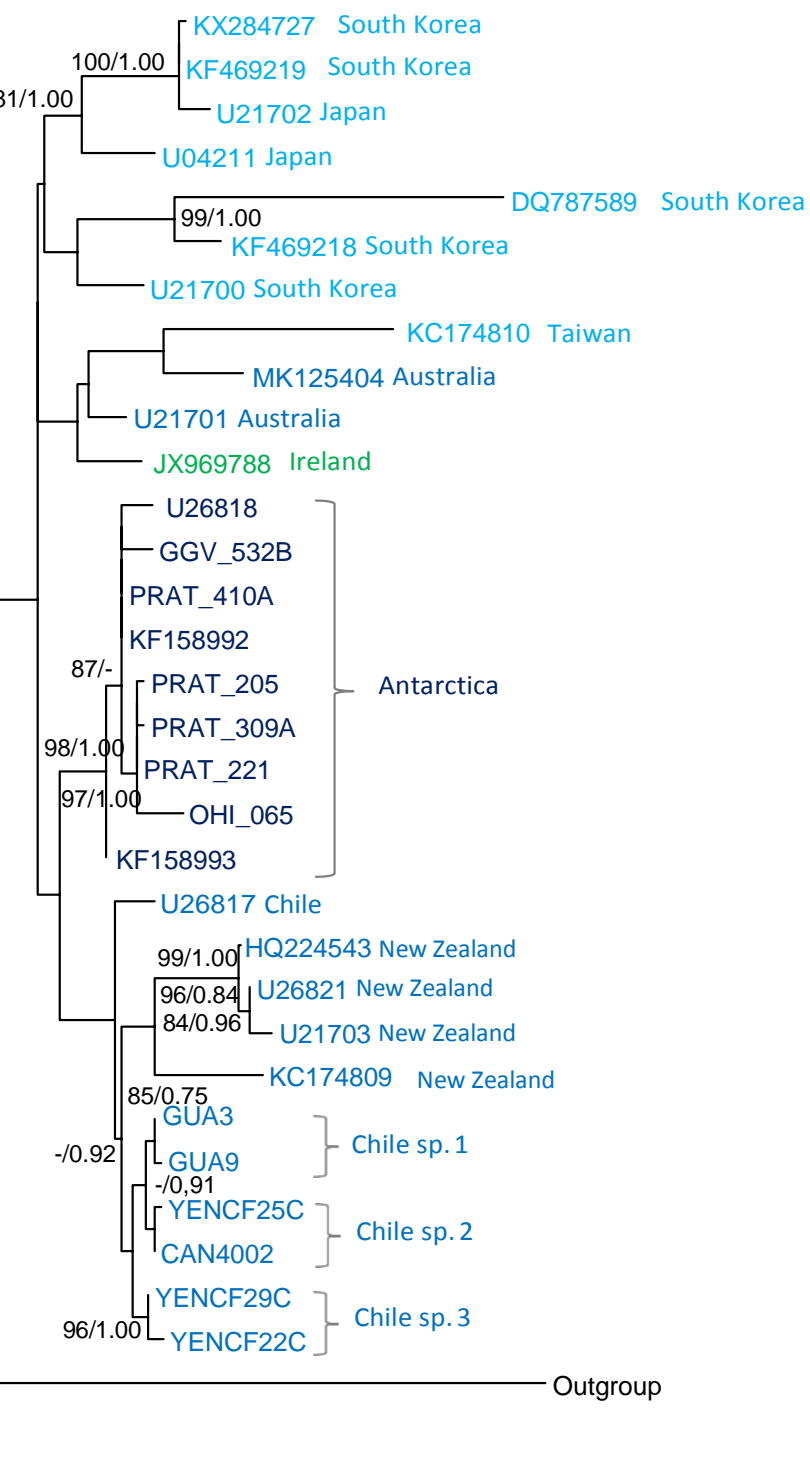

3 Figure S1 - Maximum likelihood (ML) phylogram of the genus Plocamium based on $r b c \mathrm{~L}$

4 sequences. ML bootstrap (BS)/Bayesian posterior probability (PP) values are shown above

5 or close to each branch and only values superior to 75 and 0.75 , respectively, are given.

6 Colors correspond to oceans where individuals sequenced where sampled. Outgroup

7 corresponds to Sarcodia ciliata (GenBank accession: KM360040). 
North Pacific

South Pacific

North Atlantic

Indian

Antarctic

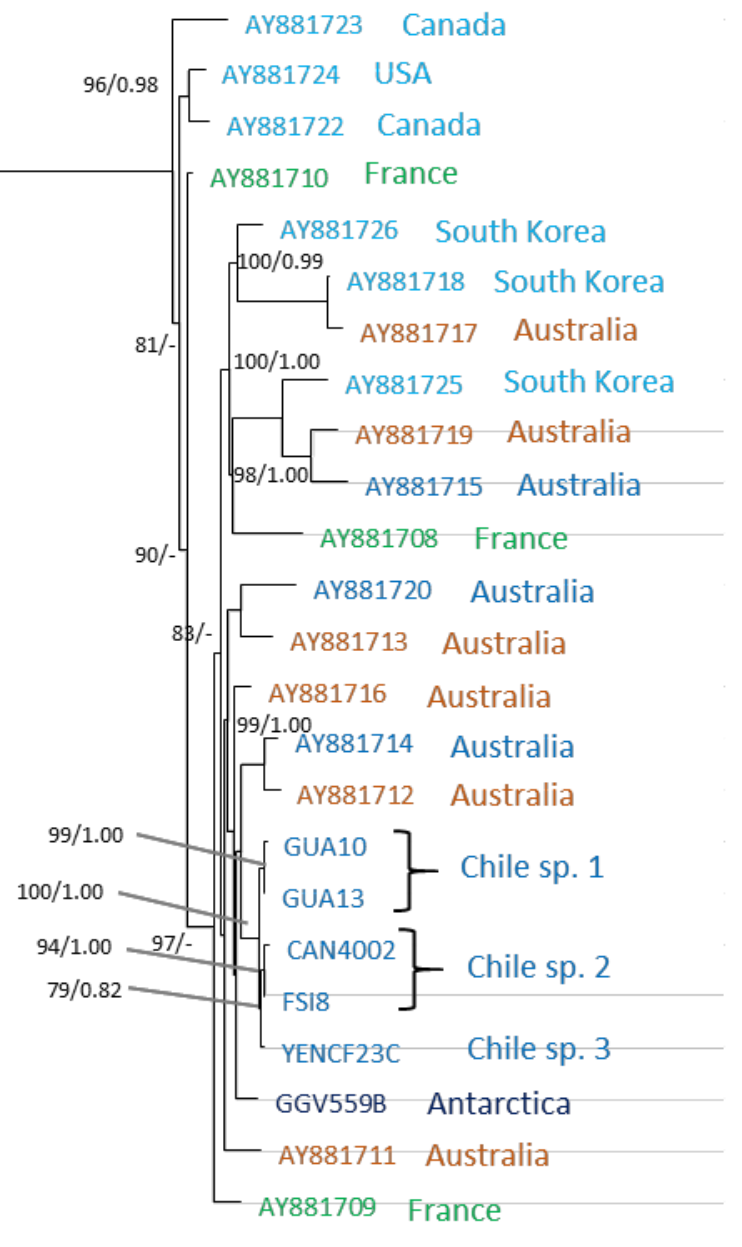

Outgroup

9

0.03

10 Figure S2 - Maximum likelihood (ML) phylogram of the genus Plocamium based on LSU

11 sequences. ML bootstrap (BS)/Bayesian posterior probability (PP) values are shown above

12 or close to each branch and only values superior to 75 and 0.75 , respectively, are given.

13 Colors correspond to oceans where individuals sequenced where sampled. Outgroup

14 corresponds to Sarcodia ciliata (GenBank accession: DQ343708). 
a)

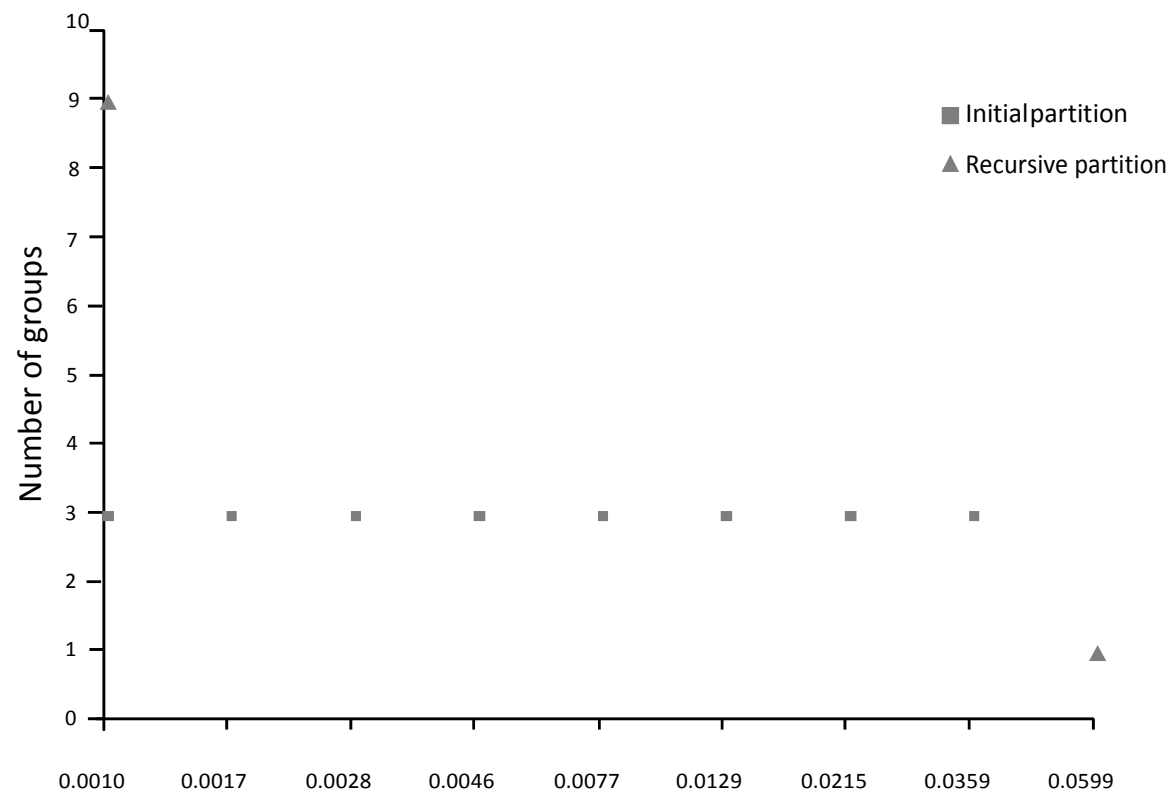

24

Prior intraspecific divergence $(P)$

25

26

27

28

29

30

31

32

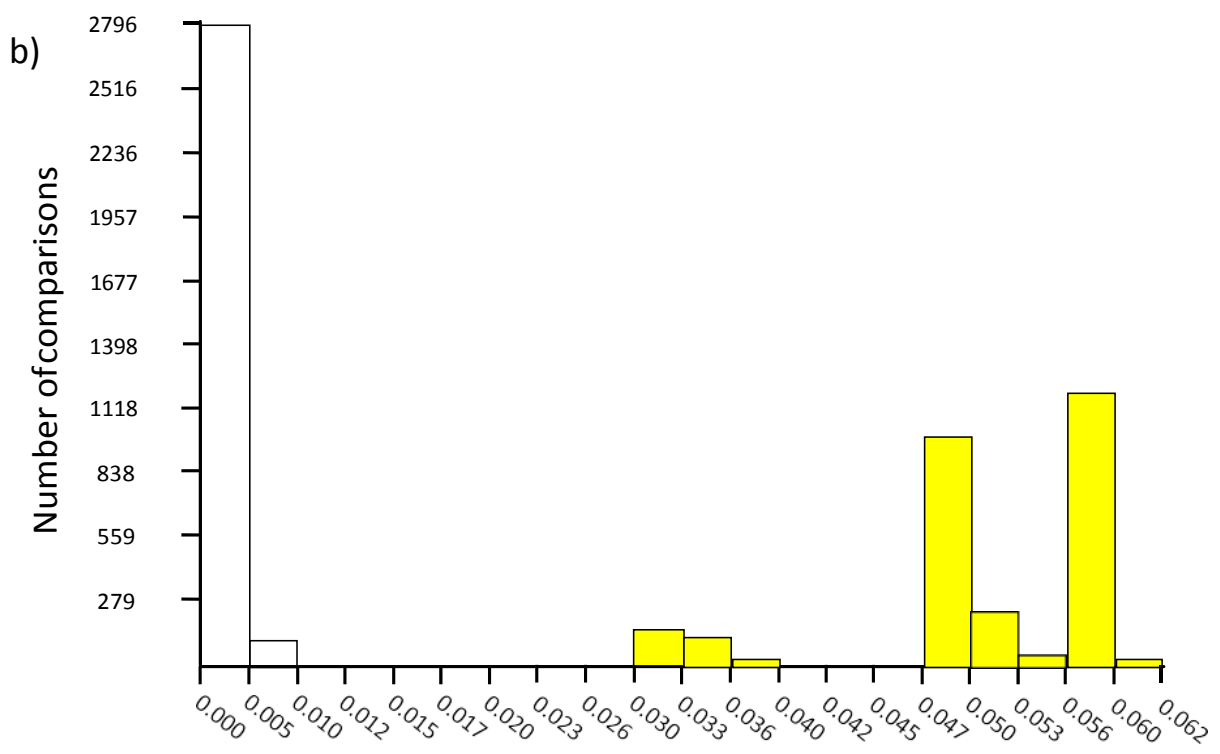

$\mathrm{K} 2 \mathrm{P}$ distance value

33 Figure S3 - Automatic Barcode Gap Discovery (ABGD) results and distribution of pairwise

34 distances for the marker 5P-COI. (a) ABGD results showing the number of groups (primary 35 partitions) obtained for a range of prior maximum divergence of intraspecific diversity. (b) 36 Bar chart showing the proportion of pairwise comparisons of 5P-COI gene at each range of

37 sequence divergence (K2P distance). Intraspecific divergences are represented in white bars 38 and divergences belonging to different species are represented in yellow bars. 


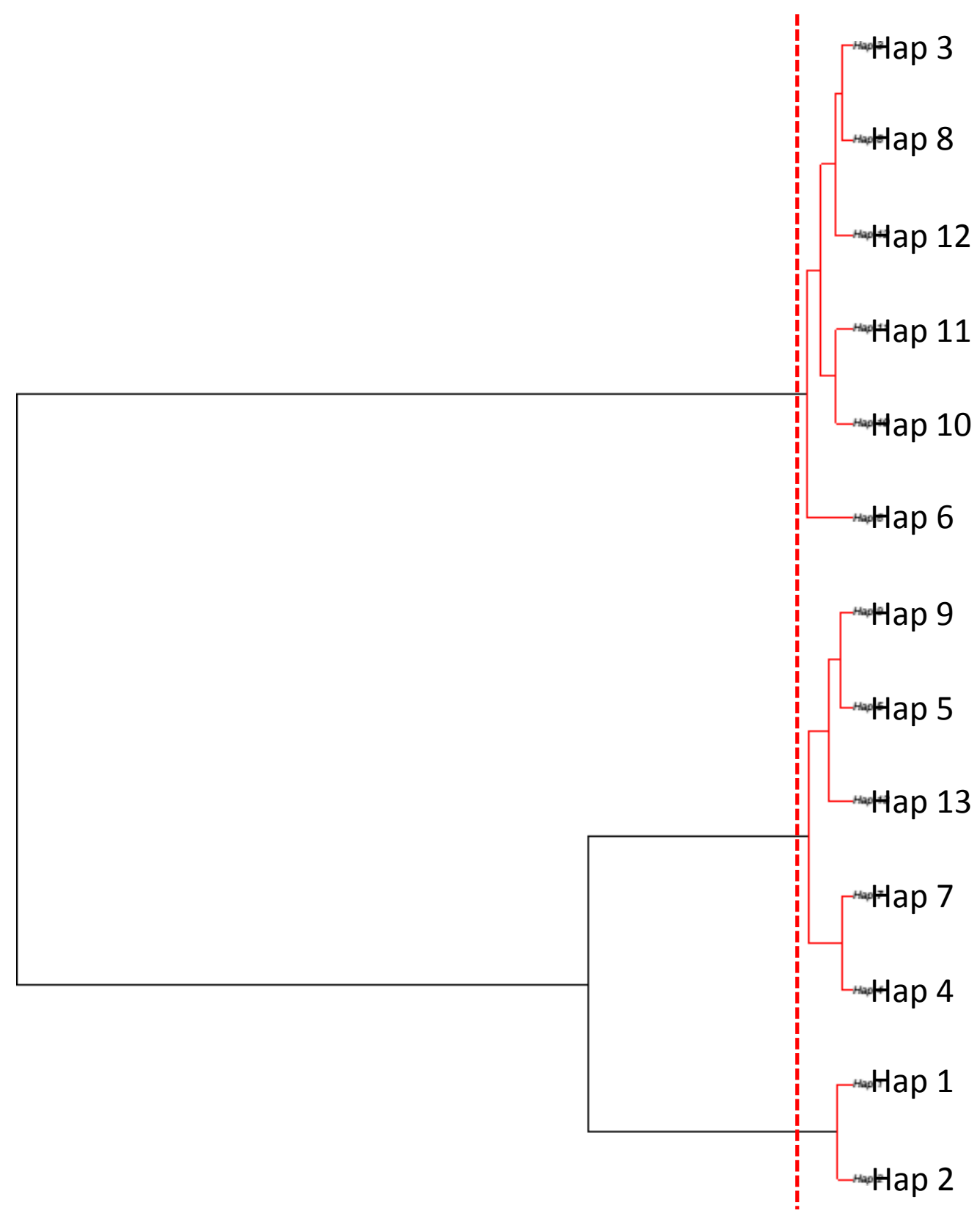

40 Figure S4 - Ultrametric Bayesian tree reconstructed with the 5P-COI marker. The dotted 41 vertical red line indicates the maximum likelihood transition point of the switch in branching 42 rates, as estimated by a General Mixed Yule-Coalescent (GMYC) model. The GMYC 43 analysis was performed using a single threshold. 
Table S1 - GenBank accession numbers of 5P-COI, $r b c \mathrm{~L}$ and LSU sequences obtained for Chilean Plocamium spp. Haplotype code for COI-5P, as in Figure 2 and 3, is given for each individual. The voucher code and phase or sex observed for deposited individuals is indicated.

\begin{tabular}{|c|c|c|c|c|c|c|c|c|}
\hline $\mathrm{N}^{\circ}$ & Sample Code & Locality & Coordinates & $\begin{array}{c}\text { GenBank } \\
\text { Accession } \\
\text { COI }\end{array}$ & $\begin{array}{l}\text { Haplotype } \\
\text { code } \\
\text { COI-5P }\end{array}$ & $\begin{array}{c}\text { GenBank } \\
\text { Accession } \\
r b c \mathrm{~L}\end{array}$ & $\begin{array}{c}\text { GenBank } \\
\text { Accession } \\
\text { LSU }\end{array}$ & Voucher code (phase/sex) \\
\hline 1 & GUA_1 & Punta Guabún & $41^{\circ} 38^{\prime} \mathrm{S} / 74^{\circ} 02^{\prime} \mathrm{W}$ & MN967353 & Hap1 & & & $\begin{array}{c}\text { SGO170286 } \\
\text { (tetrasporophyte) }\end{array}$ \\
\hline 2 & GUA_2 & Punta Guabún & $41^{\circ} 38^{\prime} \mathrm{S} / 74^{\circ} 02^{\prime} \mathrm{W}$ & MN967354 & Hap2 & & & \\
\hline 3 & GUA_3 & Punta Guabún & $41^{\circ} 38 ' \mathrm{~S} / 74^{\circ} 02^{\prime} \mathrm{W}$ & MN967355 & Hap2 & MT151849 & & \\
\hline 4 & GUA_4 & Punta Guabún & $41^{\circ} 38 ' \mathrm{~S} / 74^{\circ} 02^{\prime} \mathrm{W}$ & MN967356 & Hap2 & & & \\
\hline 5 & GUA_6 & Punta Guabún & $41^{\circ} 38^{\prime} \mathrm{S} / 74^{\circ} 02^{\prime} \mathrm{W}$ & MN967357 & Hap2 & & & \\
\hline 6 & GUA_7 & Punta Guabún & $41^{\circ} 38^{\prime} \mathrm{S} / 74^{\circ} 02^{\prime} \mathrm{W}$ & MN967358 & Hap2 & & & \\
\hline 7 & GUA_9 & Punta Guabún & $41^{\circ} 38 ' \mathrm{~S} / 74^{\circ} 02^{\prime} \mathrm{W}$ & MN967359 & Hap2 & MT151850 & & \\
\hline 8 & GUA_10 & Punta Guabún & $41^{\circ} 38^{\prime} \mathrm{S} / 74^{\circ} 02^{\prime} \mathrm{W}$ & MN967360 & Hap2 & MT151851 & MT151869 & \\
\hline 9 & GUA_11 & Punta Guabún & $41^{\circ} 38^{\prime} \mathrm{S} / 74^{\circ} 02^{\prime} \mathrm{W}$ & MN967361 & Hap2 & & & \\
\hline 10 & GUA_13 & Punta Guabún & $41^{\circ} 38^{\prime} \mathrm{S} / 74^{\circ} 02^{\prime} \mathrm{W}$ & MN967362 & Hap2 & MT151852 & MT151870 & \\
\hline 11 & GUA_14 & Punta Guabún & $41^{\circ} 38 ' \mathrm{~S} / 74^{\circ} 02^{\prime} \mathrm{W}$ & MN967363 & Hap2 & & & \\
\hline 12 & GUA_15 & Punta Guabún & $41^{\circ} 38^{\prime} \mathrm{S} / 74^{\circ} 02^{\prime} \mathrm{W}$ & MN967364 & Hap2 & & & \\
\hline 13 & GUA_16 & Punta Guabún & $41^{\circ} 38 ' \mathrm{~S} / 74^{\circ} 02^{\prime} \mathrm{W}$ & MN967365 & Hap2 & MT151853 & & \\
\hline 14 & GUA_17 & Punta Guabún & $41^{\circ} 38^{\prime} \mathrm{S} / 74^{\circ} 02^{\prime} \mathrm{W}$ & MN967366 & Hap2 & MT151854 & & \\
\hline 15 & GUA_19 & Punta Guabún & $41^{\circ} 38 ' \mathrm{~S} / 74^{\circ} 02^{\prime} \mathrm{W}$ & MN967367 & Hap2 & & & \\
\hline 16 & GUA_22 & Punta Guabún & $41^{\circ} 38^{\prime} \mathrm{S} / 74^{\circ} 02^{\prime} \mathrm{W}$ & MN967368 & Hap2 & & & \\
\hline 17 & GUA_23 & Punta Guabún & $41^{\circ} 38 ' \mathrm{~S} / 74^{\circ} 02^{\prime} \mathrm{W}$ & MN967369 & Hap2 & & & \\
\hline 18 & GRE4001A & San Gregorio & $52^{\circ} 33^{\prime} \mathrm{S} / 70^{\circ} 02^{\prime} \mathrm{W}$ & MN967421 & Hap5 & & & $\begin{array}{c}\text { SGO170291 } \\
\text { (tetrasporophyte) }\end{array}$ \\
\hline
\end{tabular}




\begin{tabular}{|c|c|c|c|c|c|c|}
\hline 19 & GRE4002B & San Gregorio & $52^{\circ} 33^{\prime} \mathrm{S} / 70^{\circ} 02^{\prime} \mathrm{W}$ & MN967422 & Hap3 & $\begin{array}{c}\text { SGO170292 } \\
\text { (tetrasporophyte) }\end{array}$ \\
\hline 20 & PCH_4008B & \begin{tabular}{|l} 
Parque \\
Chabunco
\end{tabular} & $52^{\circ} 59^{\prime} \mathrm{S} / 70^{\circ} 48^{\prime} \mathrm{W}$ & MN967423 & Hap3 & SGO170290 (female) \\
\hline 21 & PCH_4008C & $\begin{array}{l}\text { Parque } \\
\text { Chabunco }\end{array}$ & $52^{\circ} 59^{\prime} \mathrm{S} / 70^{\circ} 48^{\prime} \mathrm{W}$ & MN967424 & Hap3 & \\
\hline 22 & PCH_4009A & \begin{tabular}{|l|}
$\begin{array}{l}\text { Parque } \\
\text { Chabunco }\end{array}$ \\
\end{tabular} & $52^{\circ} 59^{\prime} \mathrm{S} / 70^{\circ} 48^{\prime} \mathrm{W}$ & MN967425 & Hap10 & SGO170293 (female) \\
\hline 23 & PCH_4009B & \begin{tabular}{|l|} 
Parque \\
Chabunco
\end{tabular} & $52^{\circ} 59^{\prime} \mathrm{S} / 70^{\circ} 48^{\prime} \mathrm{W}$ & MN967426 & Hap3 & $\begin{array}{c}\text { SGO170294 } \\
\text { (tetrasporophyte) }\end{array}$ \\
\hline 24 & PCH_4009C & $\begin{array}{l}\text { Parque } \\
\text { Chabunco }\end{array}$ & $52^{\circ} 59^{\prime} \mathrm{S} / 70^{\circ} 48^{\prime} \mathrm{W}$ & MN967427 & Hap3 & \\
\hline 25 & PCH_4010 & $\begin{array}{l}\text { Parque } \\
\text { Chabunco }\end{array}$ & $52^{\circ} 59^{\prime} \mathrm{S} / 70^{\circ} 48^{\prime} \mathrm{W}$ & MN967428 & Hap3 & \\
\hline 26 & PCH_4011 & $\begin{array}{l}\text { Parque } \\
\text { Chabunco }\end{array}$ & $52^{\circ} 59^{\prime} \mathrm{S} / 70^{\circ} 48^{\prime} \mathrm{W}$ & MN967429 & Hap3 & \\
\hline 27 & PCH_4012 & $\begin{array}{l}\begin{array}{l}\text { Parque } \\
\text { Chabunco }\end{array} \\
\end{array}$ & $52^{\circ} 59^{\prime} \mathrm{S} / 70^{\circ} 48^{\prime} \mathrm{W}$ & MN967430 & Hap3 & \\
\hline 28 & PCH_4013 & \begin{tabular}{|l|}
$\begin{array}{l}\text { Parque } \\
\text { Chabunco }\end{array}$ \\
\end{tabular} & $52^{\circ} 59^{\prime} \mathrm{S} / 70^{\circ} 48^{\prime} \mathrm{W}$ & MN967431 & Hap3 & \\
\hline 29 & PCH_4014 & \begin{tabular}{|l|} 
Parque \\
Chabunco
\end{tabular} & $52^{\circ} 59^{\prime} \mathrm{S} / 70^{\circ} 48^{\prime} \mathrm{W}$ & MN967432 & Hap3 & \\
\hline 30 & PCH_4015 & $\begin{array}{l}\text { Parque } \\
\text { Chabunco }\end{array}$ & $52^{\circ} 59^{\prime} \mathrm{S} / 70^{\circ} 48^{\prime} \mathrm{W}$ & MN967433 & Hap3 & \\
\hline 31 & PCH_4016 & $\begin{array}{l}\text { Parque } \\
\text { Chabunco }\end{array}$ & $52^{\circ} 59^{\prime} \mathrm{S} / 70^{\circ} 48^{\prime} \mathrm{W}$ & MN967434 & Hap3 & \\
\hline 32 & PCH_4018 & $\begin{array}{l}\text { Parque } \\
\text { Chabunco }\end{array}$ & $52^{\circ} 59^{\prime} \mathrm{S} / 70^{\circ} 48^{\prime} \mathrm{W}$ & MN967435 & Hap3 & \\
\hline 33 & PCH_4019 & $\begin{array}{l}\text { Parque } \\
\text { Chabunco }\end{array}$ & $52^{\circ} 59^{\prime} \mathrm{S} / 70^{\circ} 48^{\prime} \mathrm{W}$ & MN967436 & Hap3 & \\
\hline
\end{tabular}




\begin{tabular}{|c|c|c|c|c|c|c|}
\hline 34 & PCH_4020 & \begin{tabular}{|l} 
Parque \\
Chabunco
\end{tabular} & $52^{\circ} 59^{\prime} \mathrm{S} / 70^{\circ} 48^{\prime} \mathrm{W}$ & MN967437 & Hap3 & \\
\hline 35 & PCH_4022 & $\begin{array}{l}\text { Parque } \\
\text { Chabunco }\end{array}$ & $52^{\circ} 59^{\prime} \mathrm{S} / 70^{\circ} 48^{\prime} \mathrm{W}$ & MN967438 & Hap3 & \\
\hline 36 & PCH_4023 & $\begin{array}{l}\text { Parque } \\
\text { Chabunco }\end{array}$ & $52^{\circ} 59^{\prime} \mathrm{S} / 70^{\circ} 48^{\prime} \mathrm{W}$ & MN967439 & Hap3 & \\
\hline 37 & PCH_4024 & $\begin{array}{l}\text { Parque } \\
\text { Chabunco }\end{array}$ & $52^{\circ} 59^{\prime} \mathrm{S} / 70^{\circ} 48^{\prime} \mathrm{W}$ & MN967440 & Hap3 & \\
\hline 38 & PCH_4025 & $\begin{array}{l}\text { Parque } \\
\text { Chabunco }\end{array}$ & $52^{\circ} 59^{\prime} \mathrm{S} / 70^{\circ} 48^{\prime} \mathrm{W}$ & MN967441 & Hap3 & \\
\hline 39 & POR_1 & Faro Porvenir & $53^{\circ} 18^{\prime} \mathrm{S} / 70^{\circ} 27^{\prime} \mathrm{W}$ & MN967442 & Hap3 & \\
\hline 40 & POR_2 & Faro Porvenir & $53^{\circ} 18^{\prime} \mathrm{S} / 70^{\circ} 27^{\prime} \mathrm{W}$ & MN967443 & Hap3 & \\
\hline 41 & POR_3 & Faro Porvenir & $53^{\circ} 18^{\prime} \mathrm{S} / 70^{\circ} 27^{\prime} \mathrm{W}$ & MN967444 & Hap3 & \\
\hline 42 & POR_4 & Faro Porvenir & $53^{\circ} 18^{\prime} \mathrm{S} / 70^{\circ} 27^{\prime} \mathrm{W}$ & MN967445 & Hap3 & \\
\hline 43 & POR_5 & Faro Porvenir & $53^{\circ} 18^{\prime} \mathrm{S} / 70^{\circ} 27^{\prime} \mathrm{W}$ & MN967446 & Hap3 & \\
\hline 44 & POR_6 & Faro Porvenir & $53^{\circ} 18^{\prime} \mathrm{S} / 70^{\circ} 27^{\prime} \mathrm{W}$ & MN967447 & Hap5 & \\
\hline 45 & POR_7 & Faro Porvenir & $53^{\circ} 18^{\prime} \mathrm{S} / 70^{\circ} 27^{\prime} \mathrm{W}$ & MN967448 & Hap11 & \\
\hline 46 & POR_8 & Faro Porvenir & $53^{\circ} 18^{\prime} \mathrm{S} / 70^{\circ} 27^{\prime} \mathrm{W}$ & MN967449 & Hap4 & \\
\hline 47 & POR_9 & Faro Porvenir & $53^{\circ} 18^{\prime} \mathrm{S} / 70^{\circ} 27^{\prime} \mathrm{W}$ & MN967450 & Hap5 & \\
\hline 48 & POR_10 & Faro Porvenir & $53^{\circ} 18^{\prime} \mathrm{S} / 70^{\circ} 27^{\prime} \mathrm{W}$ & MN967451 & Hap3 & \\
\hline 49 & POR_12 & Faro Porvenir & $53^{\circ} 18^{\prime} \mathrm{S} / 70^{\circ} 27^{\prime} \mathrm{W}$ & MN967452 & Hap3 & \\
\hline 50 & POR_13 & Faro Porvenir & $53^{\circ} 18^{\prime} \mathrm{S} / 70^{\circ} 27^{\prime} \mathrm{W}$ & MN967453 & Hap3 & \\
\hline 51 & POR_14 & Faro Porvenir & $53^{\circ} 18^{\prime} \mathrm{S} / 70^{\circ} 27^{\prime} \mathrm{W}$ & MN967454 & Hap12 & \\
\hline 52 & POR_16 & Faro Porvenir & $53^{\circ} 18^{\prime} \mathrm{S} / 70^{\circ} 27^{\prime} \mathrm{W}$ & MN967455 & Hap3 & \\
\hline 53 & POR_17 & Faro Porvenir & $53^{\circ} 18^{\prime} \mathrm{S} / 70^{\circ} 27^{\prime} \mathrm{W}$ & MN967456 & Hap3 & \\
\hline 54 & POR_18 & Faro Porvenir & $53^{\circ} 18^{\prime} \mathrm{S} / 70^{\circ} 27^{\prime} \mathrm{W}$ & MN967457 & Hap4 & \\
\hline 55 & POR_4016A & Faro Porvenir & $53^{\circ} 18^{\prime} \mathrm{S} / 70^{\circ} 27^{\prime} \mathrm{W}$ & MN967458 & Hap5 & SGO170287 (not mature) \\
\hline
\end{tabular}




\begin{tabular}{|c|c|c|c|c|c|c|c|c|}
\hline 56 & POR_4016B & Faro Porvenir & $53^{\circ} 18^{\prime} \mathrm{S} / 70^{\circ} 27^{\prime} \mathrm{W}$ & MN967459 & Hap13 & & & $\begin{array}{c}\text { SGO170288 } \\
\text { (tetrasporophyte) }\end{array}$ \\
\hline 57 & CAN_1 & Los Canelos & $53^{\circ} 28^{\prime} \mathrm{S} / 70^{\circ} 11^{\prime} \mathrm{W}$ & MN967388 & Hap3 & & & \\
\hline 58 & CAN_2 & Los Canelos & $53^{\circ} 28^{\prime} \mathrm{S} / 70^{\circ} 11^{\prime} \mathrm{W}$ & MN967389 & Hap3 & & & \\
\hline 59 & CAN_3 & Los Canelos & $53^{\circ} 28^{\prime} \mathrm{S} / 70^{\circ} 11^{\prime} \mathrm{W}$ & MN967390 & Hap5 & & & \\
\hline 60 & CAN_4 & Los Canelos & $53^{\circ} 28^{\prime} \mathrm{S} / 70^{\circ} 11^{\prime} \mathrm{W}$ & MN967391 & Hap3 & & & \\
\hline 61 & CAN_5 & Los Canelos & $53^{\circ} 28^{\prime} \mathrm{S} / 70^{\circ} 11^{\prime} \mathrm{W}$ & MN967392 & Hap3 & & & \\
\hline 62 & CAN_6 & Los Canelos & $53^{\circ} 28^{\prime} \mathrm{S} / 70^{\circ} 11^{\prime} \mathrm{W}$ & MN967393 & Hap3 & & & \\
\hline 63 & CAN_7 & Los Canelos & $53^{\circ} 28^{\prime} \mathrm{S} / 70^{\circ} 11^{\prime} \mathrm{W}$ & MN967394 & Hap3 & & & \\
\hline 64 & CAN_8 & Los Canelos & $53^{\circ} 28^{\prime} \mathrm{S} / 70^{\circ} 11^{\prime} \mathrm{W}$ & MN967395 & Hap3 & & & \\
\hline 65 & CAN_4002 & Los Canelos & $53^{\circ} 28^{\prime} \mathrm{S} / 70^{\circ} 11^{\prime} \mathrm{W}$ & MN967396 & Hap5 & MT151864 & MT151867 & \\
\hline 66 & FSI_1 & Faro San Isidro & $53^{\circ} 46^{\prime} \mathrm{S} / 70^{\circ} 58^{\prime} \mathrm{W}$ & MN967397 & Hap3 & & & \\
\hline 67 & FSI_3 & Faro San Isidro & $53^{\circ} 46^{\prime} \mathrm{S} / 70^{\circ} 58^{\prime} \mathrm{W}$ & MN967398 & Hap3 & & & \\
\hline 68 & FSI_4 & Faro San Isidro & $53^{\circ} 46^{\prime} \mathrm{S} / 70^{\circ} 58^{\prime} \mathrm{W}$ & MN967399 & Hap6 & & & \\
\hline 69 & FSI_5 & Faro San Isidro & $53^{\circ} 46^{\prime} \mathrm{S} / 70^{\circ} 58^{\prime} \mathrm{W}$ & MN967400 & Hap3 & & & \\
\hline 70 & FSI_6 & Faro San Isidro & $53^{\circ} 46^{\prime} \mathrm{S} / 70^{\circ} 58^{\prime} \mathrm{W}$ & MN967401 & Hap3 & & & \\
\hline 71 & FSI_7 & Faro San Isidro & $53^{\circ} 46^{\prime} \mathrm{S} / 70^{\circ} 58^{\prime} \mathrm{W}$ & MN967402 & Hap3 & & & \\
\hline 72 & FSI_8 & Faro San Isidro & $53^{\circ} 46^{\prime} \mathrm{S} / 70^{\circ} 58^{\prime} \mathrm{W}$ & MN967403 & Hap4 & MT151865 & MT151868 & \\
\hline 73 & FSI_9 & Faro San Isidro & $53^{\circ} 46^{\prime} \mathrm{S} / 70^{\circ} 58^{\prime} \mathrm{W}$ & MN967404 & Hap3 & & & \\
\hline 74 & FSI_10 & Faro San Isidro & $53^{\circ} 46 ' \mathrm{~S} / 70^{\circ} 58^{\prime} \mathrm{W}$ & MN967405 & Hap7 & MT151866 & & \\
\hline 75 & FSI_11 & Faro San Isidro & $53^{\circ} 46^{\prime} \mathrm{S} / 70^{\circ} 58^{\prime} \mathrm{W}$ & MN967406 & Hap3 & & & \\
\hline 76 & FSI_12 & Faro San Isidro & $53^{\circ} 46^{\prime} \mathrm{S} / 70^{\circ} 58^{\prime} \mathrm{W}$ & MN967407 & Hap3 & & & \\
\hline 77 & FSI_13 & Faro San Isidro & $53^{\circ} 46^{\prime} \mathrm{S} / 70^{\circ} 58^{\prime} \mathrm{W}$ & MN967408 & Hap3 & & & \\
\hline 78 & FSI_14 & Faro San Isidro & $53^{\circ} 46^{\prime} \mathrm{S} / 70^{\circ} 58^{\prime} \mathrm{W}$ & MN967409 & Hap3 & & & \\
\hline 79 & FSI_15 & Faro San Isidro & $53^{\circ} 46^{\prime} \mathrm{S} / 70^{\circ} 58^{\prime} \mathrm{W}$ & MN967410 & Hap5 & & & \\
\hline 80 & FSI_16 & Faro San Isidro & $53^{\circ} 46 \mathrm{~S}^{\mathrm{S}} / 70^{\circ} 58^{\prime} \mathrm{W}$ & MN967411 & Hap5 & & & \\
\hline 81 & FSI_17 & Faro San Isidro & $53^{\circ} 466^{\prime} \mathrm{S} / 70^{\circ} 58^{\prime} \mathrm{W}$ & MN967412 & Hap3 & & & \\
\hline
\end{tabular}




\begin{tabular}{|c|c|c|c|c|c|c|c|c|}
\hline 82 & FSI_18 & Faro San Isidro & $53^{\circ} 46^{\prime} \mathrm{S} / 70^{\circ} 58^{\prime} \mathrm{W}$ & MN967413 & Hap3 & & & \\
\hline 83 & FSI_20 & Faro San Isidro & $53^{\circ} 46^{\prime} \mathrm{S} / 70^{\circ} 58^{\prime} \mathrm{W}$ & MN967414 & Hap3 & & & \\
\hline 84 & FSI_21 & Faro San Isidro & $53^{\circ} 46^{\prime} \mathrm{S} / 70^{\circ} 58^{\prime} \mathrm{W}$ & MN967415 & Hap3 & & & \\
\hline 85 & FSI_22 & Faro San Isidro & $53^{\circ} 46^{\prime} \mathrm{S} / 70^{\circ} 58^{\prime} \mathrm{W}$ & MN967416 & Hap8 & & & \\
\hline 86 & FSI_23 & Faro San Isidro & $53^{\circ} 46^{\prime} \mathrm{S} / 70^{\circ} 58^{\prime} \mathrm{W}$ & MN967417 & Hap3 & & & \\
\hline 87 & FSI_24 & Faro San Isidro & $53^{\circ} 46^{\prime} \mathrm{S} / 70^{\circ} 58^{\prime} \mathrm{W}$ & MN967418 & Hap9 & & & \\
\hline 88 & FSI_26 & Faro San Isidro & $53^{\circ} 46^{\prime} \mathrm{S} / 70^{\circ} 58^{\prime} \mathrm{W}$ & MN967419 & Hap5 & & & \\
\hline 89 & FSI_27 & Faro San Isidro & $53^{\circ} 46^{\prime} \mathrm{S} / 70^{\circ} 58^{\prime} \mathrm{W}$ & MN967420 & Hap9 & & & \\
\hline 90 & YEN_CF22C & $\begin{array}{l}\text { Fiordo } \\
\text { Yendegaia } \\
\end{array}$ & $54^{\circ} 54^{\prime} \mathrm{S} / 68^{\circ} 42^{\prime} \mathrm{W}$ & MN967370 & Hap3 & MT151855 & & \\
\hline 91 & YEN_CF23C & $\begin{array}{l}\text { Fiordo } \\
\text { Yendegaia }\end{array}$ & $54^{\circ} 54^{\prime} \mathrm{S} / 68^{\circ} 42^{\prime} \mathrm{W}$ & MN967371 & Hap3 & MT151856 & MT151871 & \\
\hline 92 & YEN_CF25C & $\begin{array}{l}\text { Fiordo } \\
\text { Yendegaia }\end{array}$ & $54^{\circ} 54^{\prime} \mathrm{S} / 68^{\circ} 42^{\prime} \mathrm{W}$ & MN967372 & Hap4 & MT151863 & & \\
\hline 93 & YEN_CF26C & \begin{tabular}{|l} 
Fiordo \\
Yendegaia \\
\end{tabular} & $54^{\circ} 54^{\prime} \mathrm{S} / 68^{\circ} 42^{\prime} \mathrm{W}$ & MN967373 & Hap3 & MT151857 & & \\
\hline 94 & YEN_CF27C & $\begin{array}{l}\text { Fiordo } \\
\text { Yendegaia } \\
\end{array}$ & $54^{\circ} 54^{\prime} \mathrm{S} / 68^{\circ} 42^{\prime} \mathrm{W}$ & MN967374 & Hap3 & MT151858 & & \\
\hline 95 & YEN_CF28C & $\begin{array}{l}\text { Fiordo } \\
\text { Yendegaia } \\
\end{array}$ & $54^{\circ} 54^{\prime} \mathrm{S} / 68^{\circ} 42^{\prime} \mathrm{W}$ & MN967375 & Hap3 & MT151859 & & $\begin{array}{c}\text { SGO170296 } \\
\text { (tetrasporophyte) }\end{array}$ \\
\hline 96 & YEN_CF29C & \begin{tabular}{|l} 
Fiordo \\
Yendegaia
\end{tabular} & $54^{\circ} 54^{\prime} \mathrm{S} / 68^{\circ} 42^{\prime} \mathrm{W}$ & MN967376 & Hap3 & MT151860 & & $\begin{array}{c}\text { SGO170297 } \\
\text { (tetrasporophyte) }\end{array}$ \\
\hline 97 & YEN_CF30C & \begin{tabular}{|l} 
Fiordo \\
Yendegaia
\end{tabular} & $54^{\circ} 54^{\prime} \mathrm{S} / 68^{\circ} 42^{\prime} \mathrm{W}$ & MN967377 & Hap3 & MT151861 & & \\
\hline 98 & YEN_CF31C & $\begin{array}{l}\text { Fiordo } \\
\text { Yendegaia } \\
\end{array}$ & $54^{\circ} 54^{\prime} \mathrm{S} / 68^{\circ} 42^{\prime} \mathrm{W}$ & MN967378 & Hap3 & & & \\
\hline 99 & YEN_CF32C & $\begin{array}{l}\text { Fiordo } \\
\text { Yendegaia } \\
\end{array}$ & $54^{\circ} 54^{\prime} \mathrm{S} / 68^{\circ} 42^{\prime} \mathrm{W}$ & MN967379 & Hap3 & & & \\
\hline 100 & YEN_CF33C & $\begin{array}{l}\text { Fiordo } \\
\text { Yendegaia } \\
\end{array}$ & $54^{\circ} 54^{\prime} \mathrm{S} / 68^{\circ} 42^{\prime} \mathrm{W}$ & MN967380 & Hap3 & & & \\
\hline
\end{tabular}




\begin{tabular}{|c|c|c|c|c|c|c|c|}
\hline 101 & YEN_CF34C & \begin{tabular}{|l} 
Fiordo \\
Yendegaia
\end{tabular} & $54^{\circ} 54^{\prime} \mathrm{S} / 68^{\circ} 42^{\prime} \mathrm{W}$ & MN967381 & Hap3 & & \\
\hline 102 & YEN_CF35C & \begin{tabular}{|l|} 
Fiordo \\
Yendegaia
\end{tabular} & $54^{\circ} 54^{\prime} \mathrm{S} / 68^{\circ} 42^{\prime} \mathrm{W}$ & MN967382 & Hap3 & & \\
\hline 103 & YEN_CF36C & \begin{tabular}{|l} 
Fiordo \\
Yendegaia
\end{tabular} & $54^{\circ} 54^{\prime} \mathrm{S} / 68^{\circ} 42^{\prime} \mathrm{W}$ & MN967383 & Hap3 & MT151862 & $\begin{array}{c}\text { SGO170298 } \\
\text { (tetrasporophyte) }\end{array}$ \\
\hline 104 & YEN_CF38C & \begin{tabular}{|l} 
Fiordo \\
Yendegaia
\end{tabular} & $54^{\circ} 54^{\prime} \mathrm{S} / 68^{\circ} 42^{\prime} \mathrm{W}$ & MN967384 & Hap3 & & \\
\hline 105 & YEN_CF39C & \begin{tabular}{|l|} 
Fiordo \\
Yendegaia
\end{tabular} & $54^{\circ} 54^{\prime} \mathrm{S} / 68^{\circ} 42^{\prime} \mathrm{W}$ & MN967385 & Hap3 & & \\
\hline 106 & YEN_CF40C & $\begin{array}{l}\text { Fiordo } \\
\text { Yendegaia }\end{array}$ & $54^{\circ} 54^{\prime} \mathrm{S} / 68^{\circ} 42^{\prime} \mathrm{W}$ & MN967386 & Hap3 & & \\
\hline 107 & YEN_CF42BC & $\begin{array}{l}\text { Fiordo } \\
\text { Yendegaia }\end{array}$ & $54^{\circ} 54^{\prime} \mathrm{S} / 68^{\circ} 42^{\prime} \mathrm{W}$ & MN967387 & Hap3 & & \\
\hline
\end{tabular}

47 